\title{
Remittances and Financial Openness
}

\author{
Michel Beine \\ Elisabetta Lodigiani \\ Robert Vermeulen
}

\author{
CESIFO WORKING PAPER NO. 3090 \\ CATEGORY 7: MONETARY POLICY AND INTERNATIONAL FinANCE \\ JUNE 2010
}

Presented at CESifo Area Conference on Macro, Money \& International Finance, February 2010

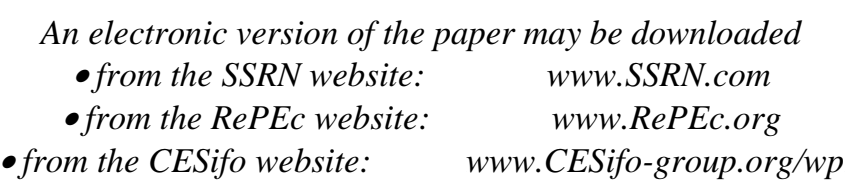




\title{
Remittances and Financial Openness
}

\begin{abstract}
Remittances have greatly increased during recent years, becoming an important and reliable source of funds for many developing countries. Therefore, there is a strong incentive for receiving countries to attract more remittances, especially through formal channels that turn to be either less expensive or less risky. One way of doing so is to increase their financial openness, but this policy option might generate additional costs in terms of macroeconomic volatility. In this paper we investigate the link between remittance receipts and financial openness. We develop a small model and statistically test for the existence of such a relationship with a sample of 66 mostly developing countries from 1980-2005. Empirically we use a dynamic generalized ordered logit model to deal with the categorical nature of the financial openness policy. We apply a two-step method akin to two stage least squares to deal with the endogeneity of remittances and potential measurement errors. We find a strong positive statistical and economic effect of remittances on financial openness.
\end{abstract}

JEL-Code: E60, F24, F41, O10.

Keywords: remittances, financial openness, government policy.

Michel Beine

CREA / University of Luxembourg michel.beine@uni.lu

\author{
Elisabetta Lodigiani \\ CREA / University of Luxembourg \\ elisabetta.lodigiani@uni.lu
}

\author{
Robert Vermeulen \\ CREA / University of Luxembourg \\ robert.vermeulen@uni.lu
}

June 2010

We would like to thank Michael Binder, Herbert Brucker, Alessandra Casarico, Yin-Wong Cheung, Paul de Grauwe, Frédéric Docquier, Giovanni Facchini, Marcel Fratzscher, Frank Heinemann, Kajal Lahiri, Concetta Mendolicchio, Joan Muysken, Gianni Toniolo, Jean-Pierre Urbain, Timo Wollmershauser, participants of the 3rd TOM conference in Hamburg, 3rd MIFN workshop in Luxembourg, macro-lunch seminar at IRES Louvain-la-Neuve, the internal seminar in Luxembourg, the seminar at IAB in Nurnberg, the APPAM conference in Maastricht and the CES-Ifo annual workshop in international macroeconomics in Munich for helpful comments. The authors gratefully acknowledge support by the Fonds National de Recherche Luxembourg under grant FNR/VIVRE/06/30/10. All errors remain ours. 


\section{Introduction}

Official global remittances sent to developing countries have reached 300 billion US dollar in 2008 and have become a significant source of income for many of these developing countries. In fact, for quite a few countries remittance receipts exceed $20 \%$ of GDP (e.g. Guyana, Honduras, Jordan and several more). These remittances appear to be a stable source of income over time , compared to e.g. foreign direct investment, and their value quite often exceeds official development aid. The importance of remittances has been recognized by policy makers, global institutions, such as the World Bank, and academics alike. ${ }^{1}$

A growing academic literature has been devoted to analyze the microeconomic and macroeconomic effects of remittances in developing countries (see Schiff and Ozden, 2006, 2007, for a synthesis). The effects of remittances on receiving countries seem indeed numerous. At a microeconomic level, remittances have been found to boost investment in human capital and educational attainments, thereby reducing poverty in many developing countries. Furthermore, there is significant evidence that remittances increase not only consumption but tend to also raise health levels and investment in public infrastructure. At a macroeconomic level, the existence of a positive relationship between remittances and growth is more controversial. While remittances tend to favor the accumulation of important production factors such as physical capital and education, they exert detrimental effects in terms of labor market incentives. They also create 'Dutch disease' effects through the appreciation of domestic currencies, leading to further deindustrialization in the receiving country. Nevertheless, the recent literature shows that appropriately used migrant remittances, combined with sound government policies, have a positive net effect on economic growth.

The growing importance of remittances and their positive impact on the economic conditions in receiving countries create for their governments strong incentives to facilitate the attraction of those flows. In some countries such as Mexico and the Philippines, explicit programs have been set up to increase the flows of the received remittances. Among the possible schemes aimed at boosting these receipts, the opening of financial borders is a possible policy instrument of governments. By decreasing the cost of the remittances sent through the official way or by relaxing the restriction of financial flows coming from abroad, governments can significantly boost the total amount of the received funds. Financial openness creates, however, new costs and risks for the receiving countries. One of the most important costs is the increased exposure to financial crises and to

\footnotetext{
${ }^{1}$ In particular, given the importance of the remittances for a large set of countries, the World Bank devoted substantial efforts to monitor, understand and forecast remittance flows. See website link www.go.worldnak.org/ssw3DDNL.
} 
macroeconomic instability. Therefore, the final decision to open the financial borders is likely to result from a trade-off between the various benefits drawn from the attracted remittances and the increased macroeconomic risk. In turn, those benefits will depend on the initial size of the incoming remittances, which depend on a set of factors unrelated to financial openness. Those factors include among others the size of the existing diaspora and their location.

In this paper, we proceed to a political economy investigation of the choice of the degree of financial openness by government with respect to their situation in terms of incoming remittances. We first develop a small model that expresses the trade off faced by government in their decision to open the financial borders. We show that the optimal degree of openness depends on the initial size of the incoming remittances which in turn depends on factors that are exogenous for the government, such as the size the total diaspora, its location or the economic conditions of the destination countries. Then, we investigate empirically that link for a sample of 66 mostly developing countries from 1980-2005. Financial openness is classified according to three regimes (closed, neutral or open) based on the KAOPEN financial openness indicator of Chinn and Itô (2008). In addition to remittances we account for institutional quality, trade openness and domestic financial development.

Empirically we use a dynamic generalized ordered logit model to establish the link between remittances and financial openness. This framework is attractive because it is well suited to deal with the ordinal nature of the financial openness indicator. Moreover, it is possible to take unobserved heterogeneity into account. In addition, we apply a two-step method akin to two stage least squares to deal with the endogeneity of remittance receipts and potential measurement errors.

To preview our results, we find a strong positive effect of remittances on financial openness. The more remittances a country receives, the more likely it will be financially open. The positive effect of remittances on financial openness is robust to instrumentation of remittances, both in a balanced and unbalanced sample.

A counterfactual analysis shows that remittances have an important effect on country's financial openness policy. Results indicate that large remittance receiving countries have a much larger probability of being financially closed when they do not receive remittances anymore.

The paper is organized as follows. We first review the existing related literature and provide some stylized facts(Section 2). In Section 3 we introduce a theoretical model that captures the trade-off between the benefits and the costs of opening the financial borders and hence the determinants of the government's decision. The empirical model and results are discussed in Section 4. In Section 5 we study two counterfactual scenarios to assess the economic importance of 
remittance receipts for individual countries. Section 6 concludes.

\section{Motivation, existing related literature and styl- ized facts}

In this section, we cover the related literature. Our paper provides a political economy analysis of the choice of financial openness based on the incentive to attract remittances from abroad. It is thus related to the literature on the effects of remittances and the one dealing with financial integration. We also provide specific examples of governmental schemes. Finally, we provide preliminary evidence in favour of a link between the cost to remit and the degree of financial openness of the receiving country.

\subsection{Related literature on the effects of remittances}

The exiting literature on the impact of remittances suggests that remittances exert important effects on the economic situation of the receiving countries.

The academic debate has focused on both micro- and macroeconomic effects of remittances. First, a number of micro studies investigate the poverty reduction effect of remittances. Country studies show that remittances play an important role in reducing poverty in e.g. Lesotho (Gustafsson and Makonnen, 1993), Guatemala (Adams, 2006) and Mexico (Acosta et al., 2006). A second strand investigates how remittance recipients spend their receipts. In general, households either consume or invest their receipts, where investment (especially in human capital) can potentially accelerate future economic growth. Recent studies (e.g. Dustmann and Kirchkamp, 2002; Cox-Edwards and Ureta, 2003; Adams, 2006) show that a sizable fraction of remittances are invested in education, health care and physical assets. Indeed, beyond the direct effect that remittances exert on spending, the fact that households receive money from abroad can be seen as a strong increase in collateral that in turn might increase investment. Remittances alleviate liquidity constraints that can act as important constrains on investment in education in a set of developing countries. In countries with a minimal level of banking development, the permanent inflow of remittances can act as a collateral for borrowing by the households. In turn, this might favour investment in human capital, small businesses or infrastructure. Finally, since remittances give rise to some increase in aggregate consumption, this leads to increase in public revenues in countries that tax consumption.

In response, macroeconomic studies started to focus on the effects of remittances on economic growth. While there is ample evidence that remittances 
reduce poverty (Adams and Page, 2005) and boost aggregate demand, the effects on growth are not clear cut. One reason is that remittances might alter the behaviour of receiving households (the so-called moral hazard effects) or induce price developments that are detrimental for the development of the country. One of these effect is the so-called Dutch Disease effect through which the flow of remittances induces a real exchange rate appreciation that affects negatively the activity of the tradable manufacturing sector (Acosta et al., 2009).

However, recent studies find that remittances have a positive impact on economic growth. Giuliano and Ruiz-Arranz (2008) show that in the economies where the financial system is underdeveloped, remittances alleviate credit constraints and work as a substitute for financial development, improving the allocation of capital and therefore accelerating economic growth. On the other hand, Mundaca (2009) shows that financial development potentially leads to better use of remittances, thus fostering growth. Recent research conducted by Aggarwal et al. (2006) also shows that remittances may directly promote financial development. In particular, they find that remittances have a significant and positive impact on bank deposits to GDP. Overall, the literature finds that net effect on growth seems to be positive, without even considering the positive impact remittances can have on the income distribution.

\subsection{Government policies}

The favourable effects of remittances on the economic situation of receiving countries have induced some governments to implement specific programs to promote remittance receipts.

The Philippines provides a clear-cut example, where the government explicitly promotes emigration to receive remittances. In 1982, the Philippine Overseas Employment Administration (POEA) has been created by Executive Order No. 797. Article I of this order clearly mentions the main objectives:

- "3. Recruitment and place workers to service the requirements of overseas employers for trained and competent Filipino workers;"

- "4. Promote the development of skills and careful selection of Filipino workers for overseas employment;"

- "\%. Generate Foreign exchange from the earnings of Filipinos employed under its programs;"

These objectives clearly show that the Philippine government's aim is to maximize remittance receipts. Moreover, articles VII and IX state the objectives even clearer: 
- "k. Formulate and implement programs for the effective monitoring of foreign exchange remittances of overseas contract workers." (Art. VII, Sec. 31)

- "4. Maximize foreign exchange generation from Filipino workers and seamen;" (Art. IX, Sec. 37)

The Mexican program Citizen Initiative $3 x 1$ (Iniciativa Ciudadana $3 x 1$ in Spanish) is another example of a government initiated scheme to promote remittance receipts from migrants. In the United States Mexican migrants run over 2000 so called Hometown Associations (HTAs), which support their local communities in Mexico. Under Citizen Initiative $3 x 1$ remittances from Mexican HTAs are matched with local, state and federal governments' funds to finance mostly basic infrastructure in rural areas. By investing in basic infrastructure, such as building roads, bridges and irrigation systems, necessary conditions are created for economic growth. In effect, remittances are generous and in some municipalities the funds received by Citizen Initiative $3 x 1$ are larger than the municipality's total budget (Orozco and Lapointe, 2004).

By matching migrant's remittances the Mexican government is able to channel remittance receipts to productive use, which benefits the country's long term growth. In addition, the development of rural areas reduces the problems induced by urbanization, e.g. lack of proper housing for Mexico City's expanding population. The success of the program is enormous and the only problem the government faces is that

"Ithe amounts committed to the program by HTAs has increased so rapidly in recent years that, at times, the government does not have the budget to match the funds" (Maimbo and Ratha, 2005, p. 123).

While some specific microeconomic programs such as those presented above might be desirable, there are complementary macroeconomic reforms that can be implemented on a larger scale. ${ }^{2}$ One example is the choice of the exchange rate regime. Freund and Spatafora (2008) find that the existence of multiple exchange rates significantly reduces the amount of recorded remittances. Singer (2009) shows that the size of incoming remittances increase the likelihood that policymakers of developing countries will adopt fixed exchange rates. Our paper considers an alternative policy option, i.e. the openness of the financial borders. Financial liberalization turns out to be a more global option encompassing the choice of the exchange rate regime. ${ }^{3}$

\footnotetext{
${ }^{2}$ For several other examples of government programs to promote remittance receipts see e.g. Maimbo and Ratha (2005).

${ }^{3}$ Our indicator of financial openness includes the existence of multiple exchange rates for instance.
} 
Financial liberalization exerts two specific effects on the flows of remittances. First, financial liberalization facilitates foreign financial transactions. In case of financial autarky, it is almost impossible for some migrants to send remittances through the formal way. While informal ways can always be relied on and are not always more expensive at first glance, these involve much more risk. Furthermore, the informal channel is often used for illegal purposes, with the danger of being considered as a criminal. ${ }^{4}$ For some pairs of countries that are quite distant, physical transportation of money might be not only dangerous but also may involve higher costs. Second, more financial openness will also lower (formal) remittances' transaction costs and will provide incentives to send remittances trough the formal market. Financial borders are often associated to controls and constraints on international financial flows such as foreign direct investments, portfolio investments and remittances sent through the banking system. This leads to an increase in the cost and to lower transfers compared to a liberalized regime.

\subsection{Stylized facts}

To illustrate the impact of financial openness on the cost of sending remittances, Table 1 provides the results of a gravity regression relating the (bilateral) cost of sending remittances from country $i$ to country $j$ and the degree of financial openness in country $j$. The cost of sending remittances denoted by $c_{i j}$ is drawn from the new dataset built by the World Bank on the remittance costs across 134 country corridors, involving 14 sending countries and 72 potential receiving countries. The data come from a survey conducted by the World Bank and are available only for 2008 and $2009 .{ }^{5}$

The World bank data include two components of the cost of remitting, i.e. the exchange rate margin associated to currency conversion and the fixed fee associated to the international transfer. The data reveals that the total cost of remitting can be substantial. Total costs of more than 15 percent are not unusual. Furthermore, those costs are observed for the most popular transfer corridors. They might be expected to be even more important for remitting between less popular country pairs. We report here the regression results obtained with the cost of sending 500 USD but we get quite the same qualitative conclusions with the other measure based on the cost of sending 200 USD.

In line with Beck and Peria (2009), we account for factors that are bilateral to $i$ and $j$, origin specific and destination specific. Since our purpose is

\footnotetext{
${ }^{4}$ See for instance http://www.interpol.int/Public/FinancialCrime/MoneyLaundering/ Hawala/default.asp about the Hawala system, one of the most popular informal channels for remittances, and money laundering.

${ }^{5}$ The full data and the related explanations are available at www.remittanceprices.org.
} 
to focus on the impact on destination specific factors such as financial openness and since our dataset is only cross-sectional, we capture the origin specific factors by fixed effects, denoted by $\alpha_{i}$. Included bilateral factors are the log of distance between the two countries, the log of the stock of migrants from country $j$ living in country $i$, the existence of colonial links and a common official language. For convenience in exposition, these factors are collected in the matrix $x_{i j, k}$ in Equation (1). The destination specific factors include some index of bank concentration (Herfindahl index) to capture the impact of bank competition (denoted by $b a n k_{j}$ ) and our index of financial integration (denoted by kaopen $_{j}$ ). The index of financial integration we use in this paper is the KAOPEN index developed by Chinn and Itô (2008). We provide more information on this indicator in Section 4.1. The higher the index, the more financially open a country is.

The estimated equation is:

$$
c_{i j}=\alpha_{i}+\beta_{1} \text { kaopen }_{j}+\beta_{2} \text { bank }_{j}+\sum_{k} \gamma_{k} x_{i j, k}+\epsilon_{i j}
$$

The results in Table 1 shed light on the relationship between financial openness and the cost of sending remittances through the official channel. In both specifications reported in Table $1, \beta_{1}$ is found to be negative and significant at the 5 percent level. The results show that the higher the openness of the receiving countries, the lower the cost to send remittances to that country, everything equal elsewhere. The results suggest that one reason to open the financial borders for governments of remittances receiving countries is to lower the transaction costs. In turn, this should increase the total amount sent by the migrants, especially since the cost is supported by them.

Table 1: Cost of remitting $\$ 500$

\begin{tabular}{lcc}
\hline \hline variable & $(1)$ & $(2)$ \\
\hline kaopen & $-0.256^{* *}$ & $-0.270^{* *}$ \\
& $(0.126)$ & $(0.125)$ \\
bank concentration host & $4.347^{* * *}$ & $3.991^{* * *}$ \\
& $(0.919)$ & $(0.842)$ \\
log(number of migrants) & -0.246 & $-0.277^{* *}$ \\
& $(0.158)$ & $(0.124)$ \\
common language & -0.385 & \\
& $(0.481)$ & \\
distance & 0.000 & \\
& $(0.000)$ & \\
colony & 0.153 & \\
& $(0.564)$ & \\
\hline Observations & 89 & 89 \\
$R^{2}$ & 0.956 & 0.955 \\
\hline \hline
\end{tabular}

Note: Estimation of Equation (1) using OLS, with robust standard errors. $*, * *, * * *$ imply significance at the $10 \%, 5 \%$ and $1 \%$, respectively. 
The World Bank dataset also reveals an important feature concerning the operating country corridors. The dataset covers 14 sending countries and 72 receiving countries. Nevertheless, prices were obtained by the surveyors of the WB only for 134 country corridors. This means that the dataset contains 87 percent of missing observations. Of course, the reasons of those missing observations might be numerous. Part of the missing data might be due to the fact that it is possible to send remittances but that the cost was unknown by the service providers at the time of the survey. In turn, the prices might be unknown because there is little demand for that particular corridor. Importantly, some missing data might also reflect that some or all service providers do not offer that service for this particular country corridor. Whatever the various reasons, the important proportion of missing data for the costs of sending remittances suggests that in many case, sending remittances through the formal channel might be cumbersome for the migrants. Part of the impossibility of sending remittances to a particular country might be due to the fact that the country is not fully opened to international financial flows.

\subsection{Financial openness as an option}

A related literature in international finance investigates the relationship between capital account/financial openness, financial development and economic growth. ${ }^{6}$ A large number of studies find a positive effect of financial openness on economic growth (e.g. Quinn, 1997; Bekaert et al., 2005; Quinn and Toyoda, 2008). However, this positive view is challenged by others (e.g. Edison et al., 2002). Klein and Olivei (2008) argue that the lack of a positive growth effect of financial openness in developing countries is due to a missing effect of financial openness on financial development for these countries. However, Chinn and Itô (2006) do find a positive effect of financial openness on domestic financial development if the institutional quality in the country is of a sufficiently high level.

The importance of threshold levels of institutional quality and macroeconomic policies has been advocated further by Kose et al. (2009). Due to the positive effects of remittances on macroeconomic stability and financial development, it is attractive for remittance receiving countries to liberalize their capital account and increase their financial openness to accelerate economic growth. Hence, remittances can have an important direct effect on a developing countries' financial openness and therefore an indirect impact on growth. However,

\footnotetext{
${ }^{6}$ Remittances are recorded in both the current and capital account of the balance of payments. Hence, when we refer to capital account/financial openness this ought to be interpreted not strictly as capital account transactions. Therefore, we use the more general term financial openness to assess the ease of sending and receiving remittances.
} 
financial openness does not only have positive effects, but also creates costs for governments. First, from the Mundell-Fleming model we know that the government needs to give up either exchange rate stability or monetary policy when allowing the free movement of capital. If the government aims to control all three factors, countries risk being hit by speculative attacks, where the only option left is to devaluate the currency. The Argentine experience during the early 2000 s is an illustrative example. In order to curtail inflation in the early 1990s Argentina pegged its currency to the US\$. Due to large public deficits (financed in part by the Central Bank) and a revaluation of the US\$ vs. the Brazilian real and the euro made Argentina's export sector uncompetitive. Hence, both imports and foreign debt increased. This resulted in a severe economic crisis and in 2002 the peg with the US\$ was abandoned.

Second, financial openness induces potential contagion effects, where healthy countries can become affected due to ill neighbors. Kaminsky and Reinhart (2000) show the important role of the financial sector and how the actions of financial market participants can lead to instability, facilitated by financial openness. This contagion risk was especially prevailing during the 1997 Asian financial crisis, where countries such as Korea had sound macroeconomic policies, but entered in economic hardship due to capital flight induced by herd behavior. In addition, financial openness increases the comovement of stock markets, especially in times of crisis (Beine et al., 2010). Hence, countries will become more integrated in the world economy and be less able to steer their own economy. The potential positive and negative effects of financial openness need to be weighted by governments in their choice regarding the degree of financial openness. More specifically for developing countries, they need to weight the positive effects of remittances to the potential risks of increased macroeconomic volatility.

\section{The Model}

This section formalizes the trade off a remittance receiving country's government faces: the positive economic effects of remittance receipts vs. potentially increasing macroeconomic instability. To keep the model tractable and intuitive, we consider a simple static model with 3 decision agents: one migrant remitter (m), one recipient household (f), which can consist of one or more individuals, and the government of the receiving household's country whose objective it is to maximize revenues. ${ }^{7}$

\footnotetext{
${ }^{7}$ In this section we want to introduce a very simple and intuitive model to provide insights in the underlying mechanisms of the government's financial openness policy. We decide to use a static model for illustrative purposes since a dynamic model will be much more complex, being beyond the scope of this section. The empirical model we are going to test includes
} 


\subsection{The household}

The representative household's utility is a function of family consumption, $z^{f}$. Family consumption depends on the family income generated in the source country, $I^{f}$, that without loss of generality can be set equal to 0 , and remittances, $R$, sent by the representative migrant remitter. Therefore the income of the family depends on remittances sent from abroad.

Even if the literature shows that remittances can be either consumed or invested in the form of land, housing acquisition, health, education, and microenterprises (for example Dustmann and Kirchkamp, 2002; Woodruff and Zenteno, 2001), for simplicity, we assume that the household consumes all the income.

More formally, considering a standard functional form for the utility function $U^{f}$, the representative household maximizes:

$$
U^{f}=\ln \left(z^{f}\right)
$$

subject to their budget constraint:

$$
z^{f}\left(1+t^{c}\right)=I^{f}+R .
$$

The price of consumption is normalized to 1 . Remittances are not directly taxed by the government, but indirectly taxed through an ad valorem consumption tax. The assumption that remittances are not directly taxed is in line with the general practice of avoiding taxing these flows by governments in the recipient countries (see for example World Bank, 2006).

\subsection{The migrant}

The representative migrant's utility $U^{m}$ depends on his own consumption, $z^{m}$, and on the utility of the recipient household, whose importance in the migrants' utility function is represented by the altruistic parameter $\gamma \in(0,1){ }^{8}$

$$
U^{m}=\ln \left(z^{m}\right)+\gamma \ln \left(z^{f}\right) .
$$

In order to determine the optimal level of remittances, the migrant maxi-

${ }^{8}$ For ease of exposition we consider only altruism as the migrant's motivation to remit, and we follow a similar way of modeling as in Rapoport and Docquier (2006) (See e.g. Rapoport and Docquier (2006) and Carling (2008) for alternative motives). Here, it is only important that the migrant is willing to remit part of his income, irrespective of the exact motives.
} 
mizes his utility function subject to his budget constraint, given by:

$$
z^{m}=I^{m}-R(1+\rho)
$$

where $z^{m}$ denotes consumption of the migrant, $I^{m}$ and $R$ denote respectively the income of the migrant and the amount of remittances. The price of consumption, as before, is normalized to 1 , therefore, prices are assumed to be the same across the host and origin country. However, this assumption does not change any of the substantive implications of the model. The cost of sending remittances depends on the parameter $\rho$, a kind of iceberg cost, which reflects the degree of financial openness of the migrant origin country. The more open the country is, the less costly is to send remittances home and vice versa. Costs can be interpreted in a broader sense, i.e. in terms of easiness of the transactions. ${ }^{9}$

Ruling out the possibility of negative transfers from the migrant to the household, the maximization problem of the migrant can be written as:

$$
\begin{aligned}
\max _{R} U^{m} & =\ln \left(I^{m}-R(1+\rho)\right)+\gamma \ln \left(\left(I^{f}+R\right) /(1+t)\right) \\
& =\ln \left(I^{m}-R(1+\rho)\right)+\gamma \ln \left(I^{f}+R\right)-\gamma \ln (1+t) .
\end{aligned}
$$

The first order condition is given by:

$$
\partial U^{m} / \partial R=-\frac{1+\rho}{I^{m}-R(1+\rho)}+\frac{\gamma}{I^{f}+R}=0,
$$

and the optimal amount of remittances is

$$
R^{*}=\frac{\gamma I^{m}}{(1+\rho)(1+\gamma)}-\frac{I^{f}}{1+\gamma}
$$

Doing some comparative-statics, it is easy to see that the model predicts that transfers to the origin household increase with the income of the migrant, $\frac{\partial R}{\partial I^{m}}>$ 0 , and with the altruistic parameter, $\frac{\partial R}{\partial \gamma}>0$, and decrease with the wealth of the origin family, $\frac{\partial R}{\partial I^{f}}<0$. Moreover, transfers are decreasing in $\rho, \frac{\partial R}{\partial \rho}<0$, predicting that the more the home country is financially closed, the less migrants are going to remit.

\footnotetext{
${ }^{9}$ The cost can be interpreted also as the "risks in sending remittances". It is plausible to think that a more open financial system provides incentives to use the formal system in sending remittances, therefore lowering the risks faced when sending money through the informal channel. A lower risk will induce more remittances. Here, we do not distinguish between formal and informal remittances, as only the formal ones are observed.
} 


\subsection{The government}

The government chooses the degree of financial openness in order to maximize its revenues, which it derives from taxing consumption. Since remittances are fully spend on consumption, the government tries to maximize remittances receipts. Hence, the government has a strong incentive to open its financial borders to attract remittances. On the other hand, controls are beneficial, because they insulate domestic markets from external shocks. Ceteris paribus, the more open a country is, the higher is capital flow volatility, the probability of external shocks and economic crises. ${ }^{10}$ Naturally, the risk of incurring a financial crisis depends on several country characteristics, e.g. institutional quality.

We introduce a simple cost function to capture the risk-cost of the government. The government incurs a country-specific cost $\xi$, which it will pay with probability $\pi \in[0,1]$. We assume that the probability is decreasing in $\rho$, and it is equal to 0 when $\rho \rightarrow+\infty$ (fully closed) and equal to 1 when $\rho=0$ (fully open).

More formally, the government maximization problem is given by

$$
\begin{aligned}
\max _{\rho} V_{g} & =z^{f} t-\pi \xi \\
& =\frac{t}{(1+t)}\left(I^{f}+R\right)-\pi \xi
\end{aligned}
$$

The first order condition is

$$
\partial V / \partial \rho=\frac{t}{(1+t)} \frac{\partial R}{\partial \rho}-\xi \frac{\partial \pi}{\partial \rho}=0 .
$$

From Equation (8) it is easy to see that $\frac{\partial R}{\partial \rho}<0$, predicting that the more financially closed the home country is, the less migrants are going to remit. At the same time $\frac{\partial \pi}{\partial \rho}$ is negative, meaning that the more the home country is financially closed, the lower the probability to pay a cost $\xi$. In order to determine the optimum level of $\rho$, the government faces the trade-off between the expected earnings that it will derive from the (indirect) taxation of remittances and the expected cost of opening, cost depending on country characteristics.

For given $t$, then the optimum $\rho$ will depend negatively on $R$ and positively on $\xi, \rho^{*}=\rho(R, \xi)$. In case of interior solution, the government may choose a $\rho^{*}$ which reflects intermediate or limited openness.

More explicitly, for analytical tractability, let's take the particular case for

\footnotetext{
${ }^{10}$ Alesina et al. (1994) list four main motives for capital controls: (i) limit volatile capital flows; (ii) maintain the domestic tax base; (iii) retain domestic savings; and (iv) sustain structural reform. Even if Alesina et al. (1994) identify the governments' attempt to collect revenue from financial repression as the main motive for controls, there are a lot of examples where financial crises were mainly due to capital flights (for example the Asian crisis in 1997).
} 
the crisis probability $\pi=\frac{1}{(1+\rho)^{2}}$. After some calculations, the optimum level of $\rho$ is given by:

$$
\rho^{*}=\operatorname{Max}\left(2 \xi \frac{1+\gamma}{\gamma} \frac{1}{I^{m}} \frac{1+t}{t}-1,0\right)
$$

Doing some comparative statics, it is easy to see that the optimum level of $\rho$ depends negatively on $I^{m}, \gamma, t$, and positively on $\xi$. This shows that the higher the cost of opening $\xi$, the higher $\rho$ (lower financial openness), and the higher the income of the migrant and its degree of altruism, the lower $\rho$ (higher financial openness). This last observation implies that the optimal level of financial openness depends positively on remittances, because remittances in their turn are positively related to $I^{m}$, and $\gamma$, and therefore related to factors which include migrants' destination country characteristics. Given $\rho^{*}$, it is possible to calculate the optimal level of remittances, $R^{*}=\frac{1}{2 \xi}\left(\frac{1+\gamma}{\gamma}\right)^{2}\left(I^{m}\right)^{2} \frac{t}{1+t}-\frac{I^{f}}{1+\gamma}$, showing that the optimal level of remittances depends negatively, among other things, on the cost of opening $\left(\frac{\partial R^{*}}{\partial \xi}<0\right)$. Therefore, the higher the cost of opening, the lower the degree of financial openness and the lower the optimal amount of remittances.

All these results provide us with a testable prediction: for given characteristics of the country, the higher the level of remittances, the more financially open the country will be. In testing for this relationship, a case for intermediate or limited openness should be accounted for. Moreover, it is important to control for reverse causality, as the migrant's decision to remit will depend on the degree of financial openness, as suggested by equation 8 .

\section{Empirical Analysis}

\subsection{Data}

\subsubsection{Measuring Financial Openness Policy}

We use the KAOPEN measure, constructed by Chinn and Itô (2008), to capture the degree of barriers to remitting money for migrants. The major advantage of this indicator is that it includes a large set of factors affecting the possibility and the cost of remitting. KAOPEN is based on the IMF's Annual Report on Exchange Arrangements and Exchange Restrictions (AREAER). The AREAER reports tables, which summarize for each country the restrictions on foreign transactions that are in place. For each type of restrictions, there is either a one if restrictions are present or zero if no restrictions are in place. However, to calculate KAOPEN these zeros and ones are reversed to construct a measure of openness, where one implies open and zero closed. 
The following four categories are considered in KAOPEN: i) The presence of multiple exchange rates $\left(K_{i t}^{1}\right)$, ii) Restrictions on current account transactions $\left(K_{i t}^{2}\right)$, iii) Restrictions on capital account transactions $\left(K_{i t}^{3}\right)$ and iv) Requirement of surrender of export proceeds $\left(K_{i t}^{4}\right)$. To calculate the third category a five year window is used: share $K_{i t}^{3}=\left(K_{i t}^{3}+K_{i, t-1}^{3}+K_{i, t-2}^{3}+K_{i, t-3}^{3}+K_{i, t-4}^{3}\right) / 5$ and KAOPEN is calculated as the first principal component of $K_{t}^{1}, K_{t}^{2}$, share $K_{t}^{3}$ and $K_{t}^{4}$.

KAOPEN's broadness is an important advantage compared to considering only a single indicator. In general, the correlation between the various components and the KAOPEN is quite high: 0.384 for $K^{1}, 0.788$ for $K^{2}, 0.83$ for $K^{3}$ and 0.88 for $K^{4}$ (Chinn and Itô, 2008). For remittances, the restrictions on current and capital account transactions are the most important categories. We will discuss in more detail how each category in KAOPEN matters for the remitting migrant.

Migrant remittances are defined as the sum of workers' remittances, compensation of employees, and migrants' transfers. The first two categories are recorded in the current account and the third in the capital account. The distinction on current and capital account depends to a large degree on the number of years the migrant lives in the sending country. However, the World Bank states: "Although the residence guideline in the manual is clear, this rule is often not followed for various reasons" (World Bank Data Factsheet). Countries do not all consistently record a certain type of transfer in the specific balance of payments account. For example, in Brazil about $20 \%$ of total remittances are recorded in the capital account. Other countries simply pool all three categories in a single account, usually the current account. Therefore there is a lot of arbitrariness. Hence, it is important to consider both restrictions on current and capital transfers to accurately capture the barriers to remit. The high correlation between KAOPEN and both these subcomponents is very important, because restrictions on these transaction channels affect remitters strongest.

Some clear examples of restrictions are the requirement to repatriate all foreign currency proceeds for residents in Morocco and Tunisia. This will discourage migrants to remit when the exchange rate is not very attractive. Furthermore, return migration is discouraged. The 2000 edition of the IMF's AREAER states for Tunisia: "Nonresident Tunisian nationals returning to definitively to the country must declare and repatriate their assets or proceeds and revenue from their holdings abroad." Some countries, e.g. the Philippines allow for foreign currency deposits. However, the 1985 AREAER states: "Philippine nationals working abroad are required to repatriate minimum shares of their foreign earnings, ranging from 50 percent to 80 percent". These conditions have been relaxed during the past decades, but are important during the time frame 
we study.

Other examples include Vietnam, which mandates migrants to invest 30 percent of their remittances in a government fund. Some countries, such as Colombia and Ecuador tax remittances, whereas others, e.g. Brazil, mandate that all foreign exchange go through the central bank (Agunias, 2006). However, during the eighties and nineties more countries imposed restrictions, but many of these were abandoned once the governments realized the positive effects of remittances. The AREAER indicates that quite a few countries require the surrender of export proceeds. This requirement is also closely related to the mandatory conversion of foreign currencies into domestic currency. While not affecting directly migrants, the requirement of surrender of export proceeds might be considered as reflecting some uncertainty regarding the extortion of remittances. Hence, including this factor in KAOPEN helps to obtain a more complete picture of the total financial openness policy of a country.

The existence of multiple exchange rates creates extra costs for migrants remitting. In fact, Freund and Spatafora (2008) show that the existence of multiple exchange rates significantly reduces the amount of recorded remittances. In addition, the World Bank data on the cost of remitting shows that there are sizeable exchange rate margins (extra costs above interbank rate) for several countries when remitting internationally. For example, when transferring from the U.S. to Brazil the average exchange rate margin is around $3 \%$, from the U.K. to Kenya 5\%, from France to Morocco 2\%, Canada to India 5\%, etcetera. There is quite some competition in these remittance corridors, so costs will be even higher for less popular country pairs. Those exchange rate margins are of course added to the fixed fee associated to the transfer.

Dual exchange rates are still in place for a large number of countries (Reinhart and Rogoff, 2004). As remitters are most likely low priority, they will not receive the most favorable exchange rate, which makes remitting less attractive. However, countries receiving large amounts of remittances are more likely to opt for a fixed exchange rate regime (Singer, 2009). Naturally, fixed exchange rates reduce the costs of remitting. Hence, we expect large remittance receiving countries to have a very low probability of a double exchange rate regime.

Quite often a dual exchange rate regime is in place after a balance of payments crisis. For example, India opted for a dual exchange rate regime in 1992 right after the balance of payments crisis of 1991. Basically, there was an official rate for selected government and private transactions and a market determined rate for all other transactions. Naturally, this market rate was worse than the official rate.

To sum up, the KAOPEN index is a broad indicator of financial openness, which captures a set of various relevant factors affecting the cost of remitting. 
It is therefore more representative of the overall policy of a country regarding its degree of financial openness. As we are interested in government policy measures, de facto indicators of financial openness policy based on parity conditions or cross border asset holdings are of limited use to address this paper's research question.

Due to its straightforward and transparent construction KAOPEN is available for virtually all countries in the world. The indicator is easily constructed and therefore annually updated. ${ }^{11}$ This large coverage is necessary to analyze the large number of countries in this study. In this paper a subset of 66 countries is considered. This restricted set of 66 countries is due to the exclusion of OECD countries and the requirement of full data availability for KAOPEN and remittances data from 1980 until 2005. Alternative financial openness policy indicators by Quinn (1997) and Miniane (2004) do not cover a large enough country span and do not fully cover the timeframe we consider. ${ }^{12}$ For the common country/timeframe KAOPEN shows a strong correlation with the other two indicators.

Figure 1 shows a quantile graph of the KAOPEN database pooling all 66 countries across all years. The values of KAOPEN range between about -1.9 and 2.6. Note that these values are not of a cardinal nature, i.e. -1 is not twice as closed as -0.5 . The higher KAOPEN the more financially open a country is.

Figure 1: Quantile graph of KAOPEN 1980-2005

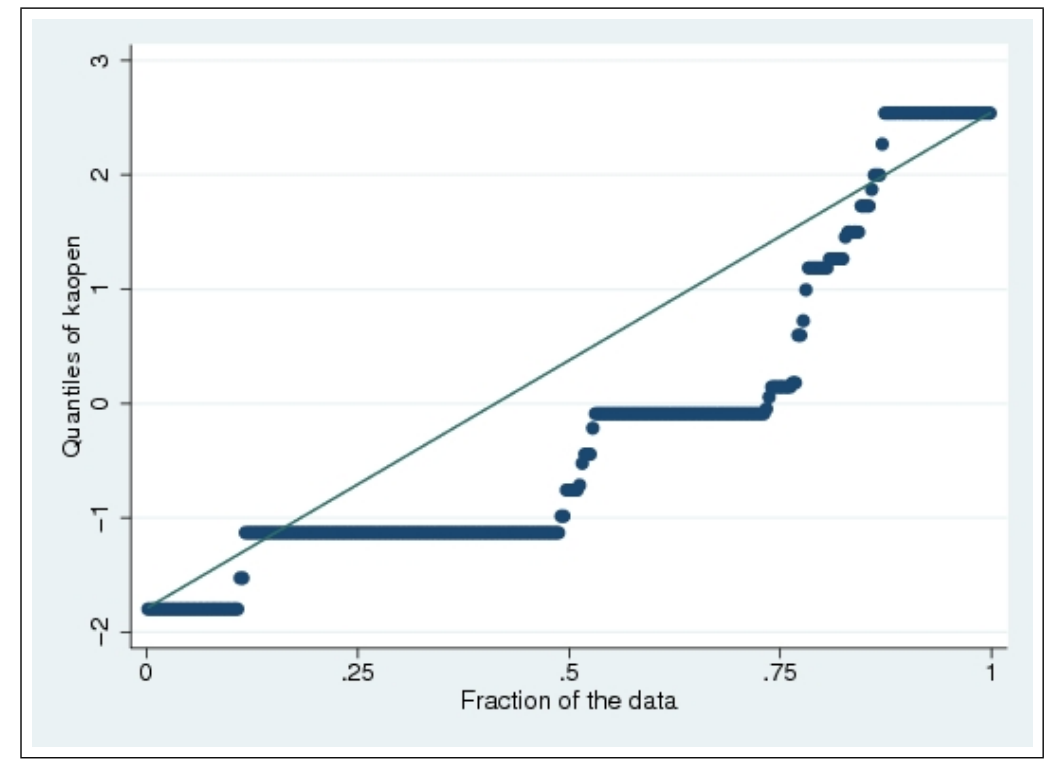

\footnotetext{
${ }^{11}$ The data and a detailed description on its construction are available at http://www.ssc.wisc.edu/ mchinn/research.html. Recently, an updated version of the database up to 2007 has been released.

${ }^{12}$ For a detailed comparison of different indicators we refer to Edison et al. (2004) and Miniane (2004).
} 
As many countries have become financially open during 1980-2005, the overall mean of KAOPEN increases over time. The largest increases took place during the 1990s when many developing countries chose to open their capital account. Another characteristic of this variable is its strong persistence over time.

A closer inspection of Figure 1 reveals that many observations have exactly the same value. There appear to be several "levels" of financial openness, with only few observations in between these levels. These levels can be associated with the number of restrictions in the subcategories of KAOPEN. The lowest level (-1.91) implies that all four subcomponents of KAOPEN are closed, the second lowest $(-1.13)$ represent that three out of four channels are closed, etcetera. The top level (2.54) represents those countries with all four categories open.

The categorical nature of KAOPEN casts doubt on the appropriateness of treating it as a continuous variable in regression models. Therefore, this characteristic will be important for our choice of estimation method. We will elaborate on this issue in Section 4.2 below.

\subsubsection{Control Variables}

Remittances. Data on remittances are taken from the World Bank and they are based on the IMF's Balance of Payments Statistics Yearbook (2008). With some exceptions, these data are constructed as the sum of three items in the Balance of Payment Statistics Yearbook: workers' remittances (part of the current transfers in the current account), compensation of employees (part of the income component of the current account), and migrant transfers (part of the capital account). More specifically, workers' remittances include current transfers made by migrants who are employed and resident in another economy, typically include transfers of workers who move to another country and stay for one year or longer; compensation of employees consists of wages, salaries and other benefits earned by nonresident workers for work performed for resident of other countries, typically include earnings from border and seasonal workers. Finally, migrant transfers comprises financial items that arise from the migration or change of residence of individuals from one economy to another.

Data from the IMF/World Bank are recognized as the best available data on remittances. Unfortunately, this data does not take into account remittances sent through informal channels (for example, money transfer that do not involve any formal contracts). Freund and Spatafora (2008) provide a table summarizing the results of earlier studies on the estimated fraction of unofficial remittances compared to official inflows in several countries. This table shows 
that are quite a few differences between countries and that the share of unofficial remittances may be quite high in some cases. For example, the share of informal remittances is quite low in Guatemala and the Dominican Republic, 5\% and $15 \%$ respectively. However, in other countries the majority of remittances received may be unofficial, e.g. Bangladesh $54 \%$ and Uganda $80 \% .{ }^{13}$

Other data. In order to explain the determinants of financial openness, data drawn from a several number of sources are considered.

Financial development measures. Measures of financial development are extracted from the data set of Beck et al. (2000). In particular we consider the ratio of bank credit over bank deposit and a measure of liquid liabilities over GDP.

Institutional quality measures. In order to consider the importance of institutional quality on the degree of financial openness, we use the composite Polity2 index from the Polity IV data set, which is the difference between the Polity's democracy and autocracy indices. It ranges from -10 (strongly autocratic countries) to +10 (strongly democratic countries). Polity IV contains annual information on regime and authority characteristics for all independent countries. Legal origin dummies, taken from La Porta et al. (1999) are also considered.

Trade Openness. It is often claimed that trade openness is a pre-condition for financial openness (e.g. Chinn and Itô, 2002; Tornell et al., 2004). To test this hypothesis a variable capturing trade openness is included. In particular, we include the updated version of Sachs and Warner's trade policy openness indicator of Wacziarg and Welch (2008).

Macro-economic control variables. To control for the level of development of the economy, per capita GDP from the World Development Indicators and income dummies according to the World Bank classification are considered.

\subsection{Gologit model}

The categorical nature of the financial openness indicator KAOPEN warrants an empirical estimation technique able to deal with this type of data. ${ }^{14}$ We choose to employ the Generalized Ordered Logit Model (gologit) for this purpose. ${ }^{15}$ The choice for the number of categories is guided by the distribution of the data in Figure 1 and the properties of the gologit model. The number of categories should be in proportion to the number of data points, i.e. choosing too many

\footnotetext{
${ }^{13}$ Possible effects of unrecorded remittances on the estimation results are discussed in Section 4.4 .

${ }^{14}$ Appendix B reports results based on estimations where KAOPEN is treated as a continuous variables. These results are discussed in Section 4.4.

${ }^{15}$ For a detailed exposition on the gologit model we refer to Williams (2006). We use Richard Williams' gologit2 Stata module to estimate the model.
} 
categories will result in estimation problems.

We opt for three financial openness categories: "closed", "neutral" and "open". A country is considered closed when it imposes restrictions on at least three of the four subcategories in KAOPEN. If there is at most one restriction on the four subcategories in KAOPEN, the country is considered to be open. When there are two restrictions out of four, the country is considered to have a neutral openness policy. Since the subcategory capital account openness is calculated over a five year period, there are points in between the levels (See Figure 1). Hence, we define the following categories: "closed" $=0$ for KAOPEN below -1.1, "neutral" = 1 for KAOPEN between -1.1 and 1 and "open" $=2$ for KAOPEN above 1. Using this choice for the categories, we can write the gologit model as

$$
\begin{aligned}
& P\left(Y_{i t}>0\right)=g\left(X_{i t} \beta_{0}\right)=\frac{\exp \left(\alpha_{0}+X_{i t} \beta_{0}\right)}{1+\left[\exp \left(\alpha_{0}+X_{i t} \beta_{0}\right)\right]}, \\
& P\left(Y_{i t}>1\right)=g\left(X_{i t} \beta_{1}\right)=\frac{\exp \left(\alpha_{1}+X_{i t} \beta_{1}\right)}{1+\left[\exp \left(\alpha_{1}+X_{i t} \beta_{1}\right)\right]},
\end{aligned}
$$

where $Y_{i t}$ is the categorical dependent variable taking values 0,1 and 2. $X_{i t}$ is a vector of independent variables corresponding to observation $i$ at time $t, \beta_{0}$ and $\beta_{1}$ are vectors of coefficients and $\alpha_{0}$ and $\alpha_{1}$ are constants.

From Equation (12) we can determine the probabilities that $\mathrm{Y}$ will take on each of the values 0,1 or 2 conditional on the explanatory variables

$$
\begin{aligned}
& P\left(Y_{i t}=0\right)=1-g\left(X_{i t} \beta_{0}\right) \\
& P\left(Y_{i t}=1\right)=g\left(X_{i t} \beta_{0}\right)-g\left(X_{i t} \beta_{1}\right) \\
& P\left(Y_{i t}=2\right)=g\left(X_{i t} \beta_{1}\right) .
\end{aligned}
$$

The gologit model is a general specification, which nests more restrictive models such as the ordered logit model (ologit). This ologit model is sometimes referred to as proportional odds model. It is more restrictive because it assumes $\beta_{0}=\beta_{1}$, i.e. it imposes the parallel lines assumption. Note that the gologit model is able to nest this assumption for all or only subset of variables. When only two categories are considered, the gologit model boils down to the familiar logit model for binary data.

We incorporate dynamics in the gologit model to capture the persistence of KAOPEN. This is done in a similar fashion as in Contoyannis et al. (2004), who introduce dynamics in an ordered probit model. Moreover, we explicitly incorporate starting values as suggested by Wooldridge (2005) to deal with the initial conditions problem in nonlinear dynamic panel data models with 
unobserved heterogeneity. So, rewriting Equation (12) as

$$
\begin{aligned}
P\left(Y_{i t}>0\right) & =\frac{\exp \left(\alpha_{0}+\bar{X}_{i, t-1 \mid t-5} \beta_{0}+Y_{i, t-5} \gamma_{0}+Y_{i, 0} \xi_{0}+\delta_{t}\right)}{1+\exp \left(\alpha_{0}+X_{i, t-1 \mid t-5} \beta_{0}+Y_{i, t-5} \gamma_{0}+Y_{i, 0} \delta_{0}+\delta_{t}\right)}, \\
P\left(Y_{i t}>1\right) & =\frac{\exp \left(\alpha_{1}+\bar{X}_{i, t-1 \mid t-5} \beta_{1}+Y_{i, t-5} \gamma_{1}+Y_{i, 0} \xi_{1}+\delta_{t}\right)}{1+\exp \left(\alpha_{1}+X_{i, t-1 \mid t-5} \beta_{1}+Y_{i, t-5} \gamma_{1}+Y_{i, 0} \delta_{1}+\delta_{t}\right)},
\end{aligned}
$$

where $Y_{i, t-5}$ is the one period lag (five years) of $Y_{i t}$ and $Y_{i, 0}$ is the initial value of $Y_{i t}$ at time $t=1980$. The matrix $X$ contains the variable of interest, the remittance/gdp ratio, and other control variables (the polity2 indicator to capture institutional quality, the Wacziarg and Welch trade openness indicator and the bank credit/ bank deposit ratio). All explanatory variables are calculated as five year averages from $\mathrm{t}-5$ until $\mathrm{t}-1$, where an average is included if the variable is available for at least three years in the $\mathrm{t}-1-\mathrm{t}-5$ time span. Time dummies are added to the model to capture common time shocks.

By using $\mathrm{t}-1-\mathrm{t}-5$ averages we avoid a potential simultaneity bias since all variables are now predetermined. However, they are not strictly exogenous.

Contoyannis et al. (2004) estimate a random effects ordered probit model, where they take explicit care of unobserved heterogeneity using random effects. As their sample is a typical micro panel, i.e. survey data, a random effects specification is more appropriate. However, in our case we are dealing with a macro panel, where one may consider introducing fixed effects to capture unobserved heterogeneity. However, when countries do not change their financial openness during 1980-2005 this is already captured by initial conditions. Consequently, by incorporating a large set of explanatory variables, initial conditions and time dummies we aim to minimize the potential bias arising from unobserved heterogeneity.

\subsection{Benchmark results}

Table 2 shows the results of the estimation of Equation (13) using five specifications, denoted (1),..,(5), on an unbalanced panel. ${ }^{16}$ For every specification there are two columns with parameter estimates, indicated by $0-2$ or 1-2. Since KAOPEN is split into three categories, we estimate two slopes inbetween these categories, i.e. from 0 to 1 and 1 to 2 . When the coefficients in columns 0-1 and 1-2 are equal, we have been able to impose slope homogeneity across the categories.

The Brant test is used to determine for which variable slope homogeneity

\footnotetext{
${ }^{16}$ Table 6 in the Appendix shows the estimation results for a balanced panel. The balanced sample consists of 43 countries. Both samples yield similar results.
} 
is imposed. First, the unrestricted model, i.e. without slope homogeneity, is estimated. For each variable, the Brant test calculates a p-value to determine if slope homogeneity is rejected or not. Second, we reestimate the model by imposing slope homogeneity on the variable with the highest p-value. Third, the Brant test is calculated again for all variables and we impose slope homogeneity for the variable with the highest p-value as well, i.e. the model is reestimated with slope homogeneity on two variables. This iterative procedure is continued until slope homogeneity is rejected significantly at $5 \%$ for all remaining variables in the model. The tables in this paper report only the results from this final model. In Table 2 we assume slope homogeneity for all variables, except for the small states variable.

Column(1) reports our baseline specification, where we account for dynamics, initial conditions, the variable of interest remittances and several control variables. First, accounting for dynamics is important when explaining the determinants of financial openness. Note that "closed" is our baseline category. For both neutral and open capital account policies the lagged openness level is an important positive determinant of current openness. This effect is especially strong for a financially open policy. Moreover, if a country is open in 1980, it is very likely to remain open as shown by the large and positive coefficient on the initial condition.

The coefficient on remittances is positive and significant at the $1 \%$ level. This implies that once a country receives more remittances, it will be more likely to liberalize its capital account, ceteris paribus. Note that the coefficients on remittances are very stable across all specifications.

Other control variables show that improved institutions increase the probability of financial openness. Moreover, a liberalized trade policy has a positive effect on financial openness as well, which is in line with the literature showing the importance of trade liberalization preceding financial liberalization. More bank credits relative to bank deposits have a positive impact on financial openness. This indicates that a more efficient domestic financial system induces the country to become more financially open. Apparently, small states have an increased probability to be open. However, the slope heterogeneity assumption does not hold here, since the coefficient for the 0-1 transition is insignificant.

In columns (2)-(5), other potential explanatory variables are added to the baseline specification. In column (2) GDP per capita is added to investigate if a country's standard of living affects its liberalization policy. This variable turns out to be insignificant. Moreover, when including income dummies in column (3), we also do not find any relationship between the income level and financial openness. One reason for these findings is that we capture GDP per capita adequately with the initial conditions, as most countries which start 


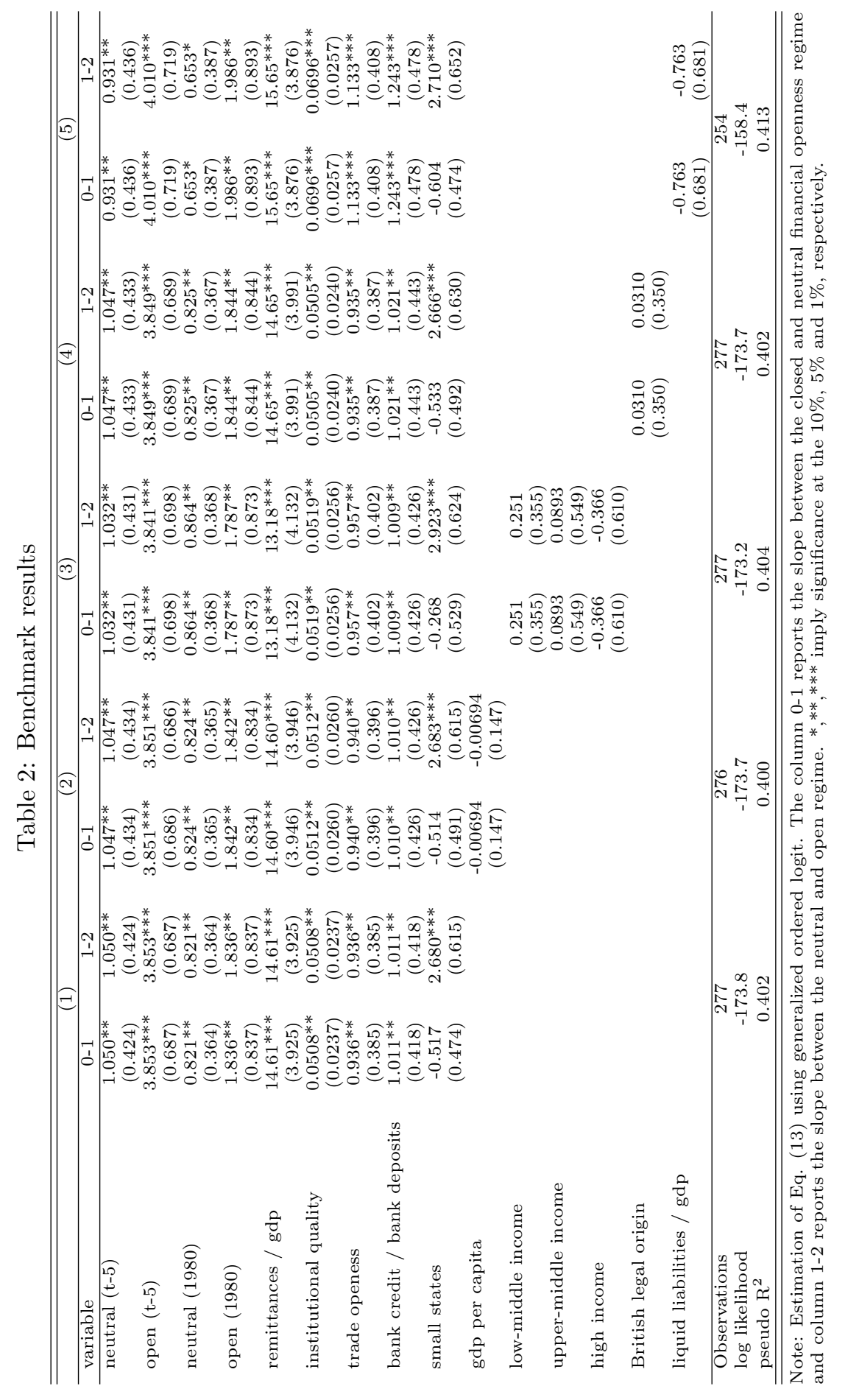


out relatively rich remain rich. Another factor that might play a role is the occurrence of an endogeneity bias, since financially liberalized countries tend to grow faster (Bekaert et al., 2005).

Some authors argue that the legal origin of a country is related to financial openness (e.g. Brune and Guisinger, 2003). Although this is likely to be captured by the initial conditions and/or institutional quality (La Porta et al., 1999), it is explicitly included in column (4). However, the coefficient on British legal origin turns out to be insignificant. Unreported results show that a French legal origin dummy is also insignificant.

As the bank credit over bank deposits ratio captures the general development level of the financial system, other variables may be included to capture additional characteristics of a country's financial development. In column (5) we incorporate the private credit over GDP ratio, which shows how large the financial sector is relative to the economy. Some authors argue (see e.g. Braun and Raddatz, 2007) that a large domestic financial system may substitute for international sources of capital financing. Hence, a large domestic financial sector may result in a more closed financial openness policy. The private credit over GDP ratio has a negative coefficient, which is in line with Braun and Raddatz (2007), but this variable is insignificant. ${ }^{17}$

Model (1) is our baseline specification and captures the most relevant variables explaining financial openness. However, there may be some distrust in the results of the estimations in Table 2 due to a potential endogeneity bias. Even though all variables are predetermined, they are not strictly exogenous. Especially, we are concerned about the potential endogeneity of remittances. The first concern is reverse causality, since the cheaper it is to remit, the higher will be remittances, ceteris paribus. Put differently, if transaction costs are very high, a migrant will not remit or remit a lower fraction of his income compared to situation without transaction costs.

A second point of concern is a potential bias due to measurement error. As the IMF/World Bank data only registers official flows, we miss those remittances sent through unofficial channels. The size of unofficial remittances is likely to be correlated with financial openness, since unofficial channels are not attractive when transaction costs of official channels are small. In order to address these concerns, we adopt an instrumental approach in the next section.

\footnotetext{
${ }^{17}$ The impossible trinity states that a country's government can pursue at most two out of the following three policies: 1. A fixed exchange rate, 2. Free capital flows and 3. An independent monetary policy. This suggests to include the country's exchange rate regime as a control variable. Unreported results, which are available upon request, show that the exchange rate regime has no impact on financial openness.
} 


\subsection{Instrumentation}

Instrumental variable (IV) methods are a common approach to deal with endogeneity problems. In linear models, the literature guiding the use of instrumentation is well developed and widespread. In particular, it is possible to use the very popular two-stage least squares technique (2SLS), and for dynamic panel data models, as in our case, the Arellano-Bover system GMM. Unfortunately, in a nonlinear framework, it is not easy to find a suitable method to account for endogeneity and there appears to be some confusion around the application of instrumental variable methods in this setting.

Very recently, Terza et al. (2008), address this issue. In the literature. there are two instrumental variables-based approaches to correct for endogeneity in non-linear models. The first one is the two-stage residual inclusion (2SRI) and the second one is the two-stage predictor substitution (2SPS). 2SPS is very similar to the linear 2SLS estimator. In the first-stage of 2SPS, reduced form regressions are estimated with any consistent estimation technique, then the results are used to generate predicted values for the endogenous variables. In the second-stage, the endogenous variables are replaced by their predicted values obtained from the first-stage. The 2SRI estimator has the same first stage as 2SPS, but in the second stage the endogenous variables are not replaced by their predicted values. Instead, the first-stage residuals are included in the second stage, reflecting the component of the error term that is correlated with the endogenous explanatory variables, and thereby correcting for endogeneity. ${ }^{18}$ Terza et al. (2008) support the use of 2SRI, showing that 2SRI is generally statistically consistent in the broader class of non-linear model, whereas 2SPS is not. Following their suggestion we use the 2SRI technique. ${ }^{19}$

A consistent estimation technique is required for first-stage estimation. In our context we apply a robust fixed effect estimation, thereby accounting for all time-constant variables explaining remittances, e.g. geographical characteristics, colonial history, linguistic and cultural features of a migrants' origin country.

Attempting to confront the endogeneity issue requires finding suitable instruments. To properly instrument remittances we need to find variables that must satisfy the following conditions: first, they need to be sufficiently correlated with the endogeneous variable (i.e. they must not be weak); and, second, they can neither have a (direct) influence on the dependent variable, capital account openness, nor be correlated with the error term in (13). Also, there must

\footnotetext{
${ }^{18}$ We recall that the essence of the endogeneity problem is the correlation between the explanatory variable and the error term

${ }^{19}$ In not reported regressions, we used also the 2SPS technique. Results were in general similar to the ones obtained with 2SRI, even if less robust in the balanced sample.
} 
be at least as many instruments as there are endogenous regressors. In our case, we need one instrument for exact identification and at least 2 instruments for overidentification.

Instrumental estimation of model (13) allows also to take into account measurement errors in the key variable, i.e. the remittances variable. As explained before, remittances are subject to measurement errors due to the fact that informal remittances are not included in the official data. The size of this measurement error is likely to vary across countries.

We consider as instruments for remittances, the (lagged) total emigration rate to the six major OECD receiving countries, considering the Defoort (2008) data set, and the growth rate of very young people (0-14) as a percentage of the total population (data are taken from the World Bank's World Development Indicators).

The emigration rate is positively correlated with remittances as a percentage of GDP, as one expect that workers from abroad send money to their family at home. At the aggregate level, therefore, the more workers migrate abroad, the larger the amounts of remittances received by their home country. Freund and Spatafora (2008) even argue that the stock of migrants in OECD countries is the primary determinant of remittances. ${ }^{20}$ Growth rate of very young population is supposed to be positively correlated with remittances, as family size increases, and in particular with more children in the family, migrants spend less on themselves, and spend more on young family members, e.g. on education, in their home country.

From our first stage estimation in Table 3, we can see that the estimated coefficients of our instruments are positive and statistically significant. They have very high joint explanatory power, which can be inferred from the high F-statistics for both the unbalanced and balances samples. This indicates that our instruments are strong. ${ }^{21}$

The second requirement for valid instruments is that they can neither have a (direct) influence on the dependent variable, financial openness, nor be correlated with the error term. In our case, we think that this is the case for both the lagged emigration rate and the growth rate of very young population.

If we do not see any direct correlation between our instruments and our dependent variable, some indirect correlation can be claimed, but from our data, this correlation appears quite weak. For example, as GDP per capita and in-

\footnotetext{
${ }^{20}$ The use of total emigration rate to the six major OECD countries as instrument for remittances as a percentage of GDP is also in line with Singer (2009) who, in his study on remittances and exchange regime policies, uses as instrument for remittances the five-year rolling average annual emigration to 15 advanced industrial countries, scaled by the sending country's population.

${ }^{21}$ In general, practitioners consider instruments as strong when the F-statistic is larger than ten.
} 
Table 3: First stage

\begin{tabular}{lcc}
\hline \hline variable & unbalanced & balanced \\
\hline neutral (t-5) & $0.00768^{* *}$ & $0.00976^{* *}$ \\
& $(0.00332)$ & $(0.00385)$ \\
open (t-5) & 0.00459 & 0.00433 \\
& $(0.00542)$ & $(0.00655)$ \\
emigration rate (t-5) & $0.684^{* * *}$ & $0.673^{* * *}$ \\
& $(0.136)$ & $(0.145)$ \\
growth rate young population & $0.123^{* *}$ & $0.129^{* *}$ \\
& $(0.0581)$ & $(0.0615)$ \\
institutional quality & $-0.000594^{*}$ & -0.000441 \\
& $(0.000349)$ & $(0.000378)$ \\
trade openess & -0.00124 & -0.000333 \\
& $(0.00552)$ & $(0.00666)$ \\
bank credit / bank deposits & $-0.00833^{*}$ & $-0.0106^{* *}$ \\
& $(0.00431)$ & $(0.00516)$ \\
\hline Observations & 277 & 215 \\
R-squared & 0.385 & 0.391 \\
Number of countries & 66 & 43 \\
F-stat & 29.76 & 25.24 \\
p-value (F-stat) & 0.000 & 0.000 \\
partial R ${ }^{2}$ & 0.2526 & 0.2489 \\
\hline \hline
\end{tabular}

Note: Estimation of first stage regression with remittances/gdp as dependent variable using fixed effects and robust standard errors. ${ }^{*}, * *, * *$ imply significance at the $10 \%$, $5 \%$ and $1 \%$, respectively.

come dummies are not significant in our benchmark estimation, we can exclude that the growth rate of very young population is correlated with our dependent variable through GDP per capita (population growth and GDP per capita are negatively correlated, as rich countries usually have a lower population growth rate). For the emigration rate, one can claim that the emigration rate is potentially correlated with capital account openness through institutional quality, considering capital account openness as a reflection of institutions. There are some papers assessing the relationship between migration and political institutions (e.g. Spilimbergo, 2009). Even if in our estimation, institutional quality is positive and highly significant, financial openness and institutional quality, measured as a corrected indicator of democracy, are unconditionally uncorrelated (for instance, there are very open countries with low level of democracy), therefore excluding a possible correlation between emigration rate and financial openness through institutional quality. ${ }^{22}$

In order to statistically test for correlation of our instruments with the error term, an over-identifying restrictions test has been performed. This test is a likelihood ratio test which compares the likelihood function of the two-stage estimates with the likelihood function of a specification which additionally includes our instruments. This test confirms the validity of our instruments both

\footnotetext{
${ }^{22}$ We consider the unconditional correlation between Kaopen and the Polity2 measure from the Polity IV data set. The correlation is 0.0713 with a p-value of 0.1395 .
} 
for the unbalanced and the balanced sample.

Table 4 shows the second-stage gologit results. The estimated coefficients of the residuals are positive and statistically significant in columns $0-1$, negative and less significant in columns 1-2; they either test for endogeneity and capture the component of the error term correlated with the endogenous explanatory variables. Even correcting for endogeneity, the coefficient on remittances is positive and highly significant at the $1 \%$ level, with only a minor lower estimated coefficient compared to our benchmark estimation, both in the unbalanced and balanced sample. The residual variable in this second stage estimation is significantly different from zero in 3 out of the 4 equations reported in the Table. The significance of this variable can be seen as some indirect evidence of the need to instrument the remittance variable. In turn, in the spirit of the well-known Hausman test in the case of continuous models, this might provide indirect evidence in favour of reverse causality between financial openness and remittances. This interpretation should be nevertheless taken with caution. ${ }^{23}$

Table 4: Instrumentation Second Stage Gologit

\begin{tabular}{|c|c|c|c|c|}
\hline \multirow[b]{2}{*}{ variable } & \multicolumn{2}{|c|}{ unbalanced } & \multicolumn{2}{|c|}{ balanced } \\
\hline & $0-1$ & $1-2$ & $0-1$ & $1-2$ \\
\hline neutral (t-5) & $\begin{array}{c}1.167^{* * *} \\
(0.430)\end{array}$ & $\begin{array}{c}1.167^{* * *} \\
(0.430)\end{array}$ & $\begin{array}{l}1.322^{* *} \\
(0.523)\end{array}$ & $\begin{array}{l}1.322^{* *} \\
(0.523)\end{array}$ \\
\hline open $(t-5)$ & $\begin{array}{c}3.937^{* * *} \\
(0.687)\end{array}$ & $\begin{array}{c}3.937^{* * *} * \\
(0.687)\end{array}$ & $\begin{array}{c}3.666^{* * *} \\
(0.770)\end{array}$ & $\begin{array}{c}3.666^{* * *} \\
(0.770)\end{array}$ \\
\hline neutral (1980) & $\begin{array}{c}0.859^{* *} \\
(0.372)\end{array}$ & $\begin{array}{c}0.859 * * \\
(0.372)\end{array}$ & $\begin{array}{c}0.287 \\
(0.460)\end{array}$ & $\begin{array}{c}0.287 \\
(0.460)\end{array}$ \\
\hline open $(1980)$ & $\begin{array}{c}1.717^{* *} \\
(0.851)\end{array}$ & $\begin{array}{l}1.717^{* *} \\
(0.851)\end{array}$ & $\begin{array}{c}1.290 \\
(0.854)\end{array}$ & $\begin{array}{c}1.290 \\
(0.854)\end{array}$ \\
\hline remittances / gdp & $\begin{array}{c}13.19^{* * *} \\
(4.299)\end{array}$ & $\begin{array}{c}13.19^{* * *} \\
(4.299)\end{array}$ & $\begin{array}{c}14.01^{* * *} \\
(4.058)\end{array}$ & $\begin{array}{c}14.01^{* * *} * \\
(4.058)\end{array}$ \\
\hline institutional quality & $\begin{array}{c}0.0517^{* *} \\
(0.0244)\end{array}$ & $\begin{array}{c}0.0517^{* *} \\
(0.0244)\end{array}$ & $\begin{array}{c}0.0789^{* *} \\
(0.0332)\end{array}$ & $\begin{array}{c}0.0789 * * \\
(0.0332)\end{array}$ \\
\hline trade openess & $\begin{array}{c}0.988^{* *} \\
(0.390)\end{array}$ & $\begin{array}{c}0.988^{* *} \\
(0.390)\end{array}$ & $\begin{array}{l}1.198^{* *} \\
(0.491)\end{array}$ & $\begin{array}{l}1.198 * * \\
(0.491)\end{array}$ \\
\hline bank credit / bank deposits & $\begin{array}{c}0.969^{* *} \\
(0.430)\end{array}$ & $\begin{array}{c}0.969 * * \\
(0.430)\end{array}$ & $\begin{array}{c}2.866^{* * *} \\
(0.656)\end{array}$ & $\begin{array}{c}-0.484 \\
(0.872)\end{array}$ \\
\hline small states & $\begin{array}{l}-0.608 \\
(0.445)\end{array}$ & $\begin{array}{c}2.551^{* * *} \\
(0.627)\end{array}$ & $\begin{array}{c}-1.259^{* *} \\
(0.573)\end{array}$ & $\begin{array}{c}2.304^{* * *} \\
(0.833)\end{array}$ \\
\hline residual & $\begin{array}{c}33.08^{* *} \\
(13.95)\end{array}$ & $\begin{array}{c}-15.60 \\
(15.89)\end{array}$ & $\begin{array}{c}57.93^{* * *} \\
(15.74)\end{array}$ & $\begin{array}{c}-26.51^{*} \\
(15.24)\end{array}$ \\
\hline Observations & & & & \\
\hline log likelihood & & & & \\
\hline pseudo $\mathrm{R}^{2}$ & & & & \\
\hline Overid (LR test, $\mathrm{p}$-val) & & & & \\
\hline
\end{tabular}

Note: Estimation of Equation (13) using generalized ordered logit. The column 0-1 reports the slope between the closed and neutral financial openness regime and column 1-2 reports the slope between the neutral and open regime. $*, * *, * * *$ imply significance at the $10 \%, 5 \%$ and $1 \%$, respectively.

\footnotetext{
${ }^{23}$ In the same perspective, it is impossible to assess the degree of reverse causality in our data from the mere comparison between estimates of Table 2 and of Table 4 . The reason is that with respect to the basic estimates of the gologit model, the IV estimates correct for two different biases, i.e. the simultaneity bias and the measurement error one.
} 
Now initial conditions are less important than previous estimation for the balanced sample. All the other results for our benchmark specification are confirmed.

In order to assess the robustness of our results we treat the dependent variable, financial openness, as a continuous variable using two different estimation techniques. First, we re-estimate our model using a linear 2SLS technique, considering the same set of instruments as before. Second, with the Arellano-Bover system GMM, considering the lagged dependent variable as predetermined, and remittances as endogenous and instrumented by their second and further lags. The regression results are reported in Appendix B. Also in these cases our main results are confirmed: the estimated coefficient of remittances is positive and significant at usual statistically level in both cases.

One concern with the results of Tables 2 and 4 is the quality of the remittances variable. As mentioned before, there is only data available for official remittance flows, i.e. unofficial remittances are not captured in the data. Suppose all countries have a certain fraction of remittances received through informal channels in 1980. The potential effect on financial openness is captured by the initial conditions. Over time the fraction official vs. unofficial remittances is likely to increase. Due to financial innovations, official transactions have become cheaper since the 1980s. Consequently, we would expect that the increase in official remittances is larger than the increase in total remittances. In this case, the coefficient on remittances in Tables 2 and 4 is underestimated and the effect of remittances on capital account openness is even stronger than the estimated one.

\subsection{Marginal effects}

From the estimated coefficients in Table 4 it is possible to calculate marginal effects. These marginal effects are calculated at the mean of each independent variable for all categories. Table 5 shows these marginal effects for both the unbalanced (left panel) and balanced sample (right panel). The interpretation of the coefficients is straightforward. Consider remittances in the unbalanced panel, the coefficient of about -3 implies that if the remittance over GDP ratio increases by one percentage point (e.g. from 2 to 3 percent), then this decreases the probability of ending up in a closed regime by 3 percentage points. Likewise, a one percentage point increase in remittances/GDP results increases the probability of ending up in the category neutral (open) by 2 (1) percentage point(s). These results show that countries which receive large amounts of remittances from abroad are unlikely to be financially closed, e.g. a ten percentage point increase in remittances reduces the probability of being in a closed regime by 
thirty two percentage points.

The coefficients on the lagged categories can be interpreted as transition probabilities. If a country has a neutral financial openness policy at t-5, it is unlikely to end up in a closed regime at time t. Put differently, the probability of ending up in a closed regime is reduced by 27 percentage points if a country has a neutral regime at $t-5$. This effect is even stronger when a country has an open financial policy at t-5 (-55 percentage points). Countries that have an open financial regime are likely to remain open. The probability of a country to be open at time $t$, when it is open at time $t-5$, increases by 66.7 percentage points.

Initial conditions do not seem to matter for the balanced sample, implying that countries are not "stuck" in a regime. Instead they are able to switch regimes when e.g. remittances increase strongly during the 1980-2005 period. For the unbalanced sample initial conditions do seem to matter, e.g. if you have a neutral regime in 1980 this increases the probability of being in a neutral regime in the future by 13 percentage points. Moreover, the probability to end up in a closed regime is reduced by 20 percentage points.

The quality of institutions has a positive effect on the probability of being in a neutral or open regime, i.e. countries with good institutions are less likely to have a closed financial regime.

Financial openness appears to go hand in hand with trade openness. Countries with a closed trade policy are unlikely to have an open capital account policy. This finding is related to McKinnon (1991) who argues that trade openness is prerequisite for financial openness. Empirical evidence in favor of this reasoning has been provided by, among others, Chinn and Itô (2006). The findings in Table 5 are in line with this reasoning.

Economically, the size of this effect is large. When a country liberalizes its trade account, this reduces the probability of ending up in a closed regime by about $24 \%$ (or $29 \%$ in the balanced sample). Therefore, an increase in the remittance/gdp ratio of seven percentage points is similar in magnitude as a change from a closed to open trade regime. Note that the relative importance of trade openness and remittances is similar across financial openness regimes. With quite a few countries receiving remittances in excess of $10 \%$ of GDP, the importance of remittances is very obvious.

A higher bank credit/bank deposits ratio lowers the probability of a country to be financially closed. This implies that countries with more developed financial systems are more likely to have a neutral or open financial policy.

Small countries have a higher probability of being either closed or open. Apparently, governments of small states choose one of these extreme policies and have less preference for a neutral financial openness policy. 


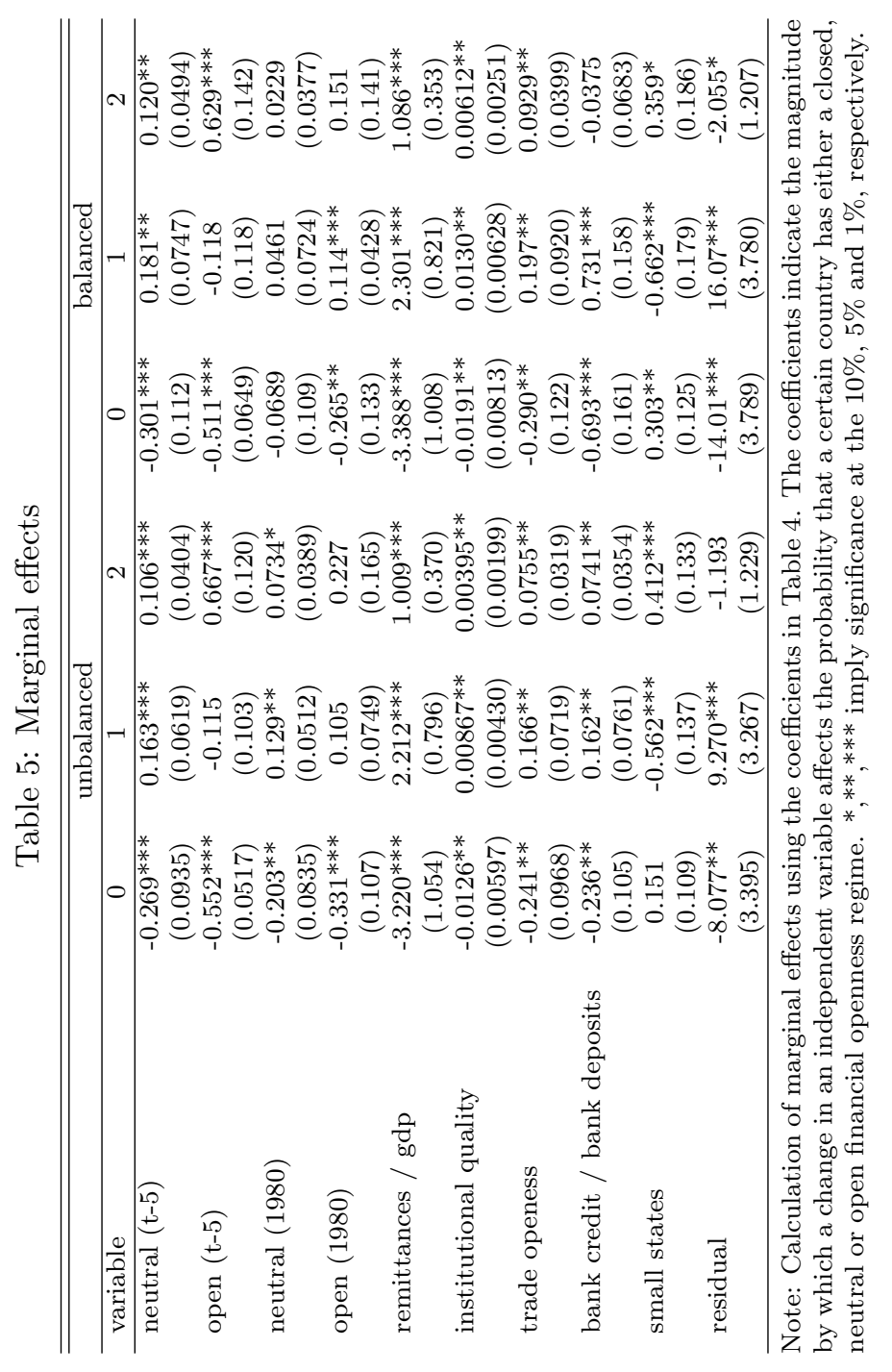


In sum, Table 5 confirms the predictions of the positive effect of remittances on a country's financial openness policy. Moreover, the impact of remittances on financial openness is not only statistically significant, but also economically large.

\section{Counterfactual analysis}

In order to further assess the economic effect of remittances, we investigate what the financial openness policy of a country would be under different scenarios. By keeping other country characteristics fixed at their observed values and varying only the amount of remittances received, the objective is to gain insight on the economic importance of remittances. We consider two specific scenarios. In the first scenario we show how the distribution of financial openness changes when a country receives zero remittances. The second scenario investigates the case when the amount of remittances received is doubled. We hypothesize, based on the results obtained in Sections 5.3 and 5.4, that large remittance receiving countries will have a lower financial openness in the first scenario and a higher financial openness under the second. Naturally, for countries receiving relatively few remittances we do not expect large effects on financial openness.

In Section 5.4 we calculated the marginal effects of each variable for the average country in the sample. This provides insights on the effects of a change in e.g. remittances for the "average country". Instead of using the average country's data, here country specific data will be used to calculate the country specific marginal effects. From these country specific characteristics, the estimated model parameters and the distributional properties of the logit model, we are able to calculate for each country individually the probabilities of ending up in a specific financial openness regime. ${ }^{24}$

The intuition of the technique is straightforward when illustrating it for an individual country, say the Dominican Republic. The characteristics of this country, when predicting its 2005 financial openness regime, are as follows: 1 ) Financial openness in 1980 was "closed" and in 2000 it was "neutral", 2) The remittances/gdp ratio during 2000-2004 is $0.11,3)$ It scored an 8 for institutional quality during these years, 4) The country is open to trade, 5) Its bank credit/bank deposit ratio during 2000-2004 is 1.43 and 6) it is considered to be a small state. Under these conditions the model predicts the following regime probabilities for the Dominican Republic in 2005: 7\% "closed", 51\% "neutral" and $42 \%$ "open".

Since the Dominican Republic's remittances/gdp ratio is $11 \%$, this will be

\footnotetext{
${ }^{24}$ The $\mathrm{mfx}$ postestimation command in Stata is used to calculate these probabilities.
} 
set to $0 \%$ in scenario 1 and doubled to $22 \%$ in scenario 2 . Keeping all other variables constant we now obtain the following probabilities in scenario 1: $25 \%$ "closed", $61 \%$ "neutral" and 14\% "open". Under scenario 2 this is: $2 \%$ "closed", $22 \%$ "neutral" and $76 \%$ "open". These numbers show the important impact remittances have on the Dominican Republic's financial openness policy regime. Therefore, remittances strongly impact the prospects of ending up in either the neutral or open regime. Based on the country's other characteristics there is a relatively small, but not negligible, $25 \%$ probability of ending up in the closed regime when no remittances are received. ${ }^{25}$

Figure 2 presents the changes in probabilities to end up in one of the 3 categories as a function of the average remittances/GDP ratio during 20002004 when a country receives zero remittances. It is easy to see that the higher the remittances/gdp ratio the higher the probability to become more closed. All countries face an increase in the probability to move to a lower financial openness category.

Let us focus on some particular countries, as an example. Jamaica is in an open regime in 2000 and receives a large amount of remittances relative to GDP. In the case of zero remittances, the probability to end up in an open regime widely decreases, while the probability to end up in a neutral regime increases. The probability to end up in a closed regime will be slightly affected.

Consider now the Philippines, a country which is intermediate open in 2000 and receiving a large amount of remittances. We can see that both the probability to be in an open or neutral regime will decrease, while the probability to end up in a closed regime increases. The same happens for countries with an intermediate amount of remittances and which are in a closed regime in 2000, such as Morocco.

On the opposite, the probabilities to end up in a certain regime will generally not change when the remittances/GDP ratio is very low. For example, Mexico is in an open regime in 2000 and does not receive that many remittances (in terms of GDP only $2 \%$, in absolute terms the figure is large), therefore its probability to have an open regime is unaffected in case it receives no remittances anymore.

Figure 3 presents the changes in probabilities to end up in one of the 3 categories as a function of remittances/GDP ratio in 2000 when the amount of remittances received is doubled. In general, the results of scenario 2 show the reverse pattern of scenario 1 .

Countries such as Jamaica, which are open and receive already a large amount of remittances, would face an increase in the probability to stay in the open regime. It is interesting to note, that countries like Morocco and

\footnotetext{
${ }^{25}$ Table 8 shows in detail the probabilities for all the countries in the baseline case and the two scenarios
} 
Figure 2: Scenario 1 (zero remittances)
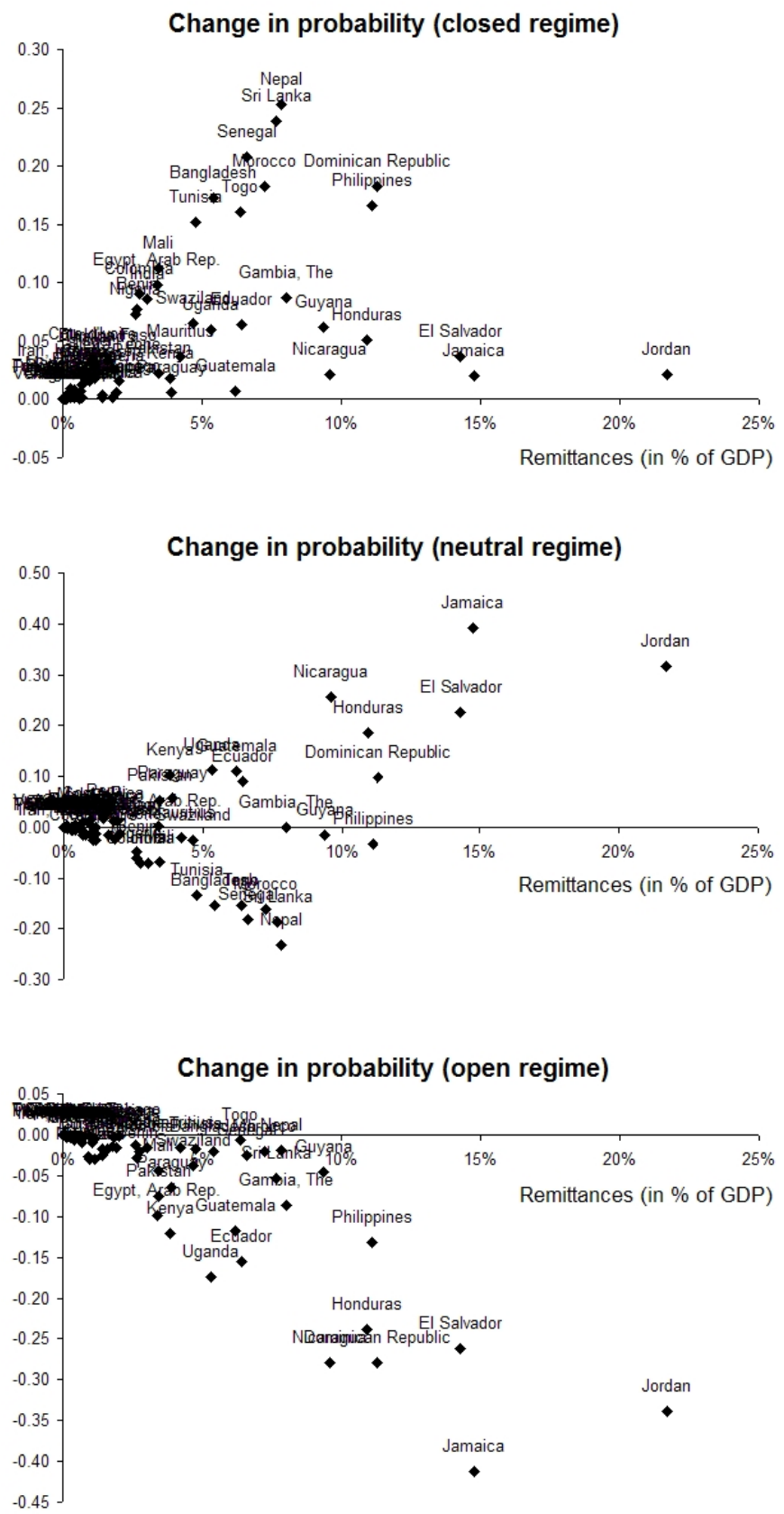
Figure 3: Scenario 2 (double remittances)
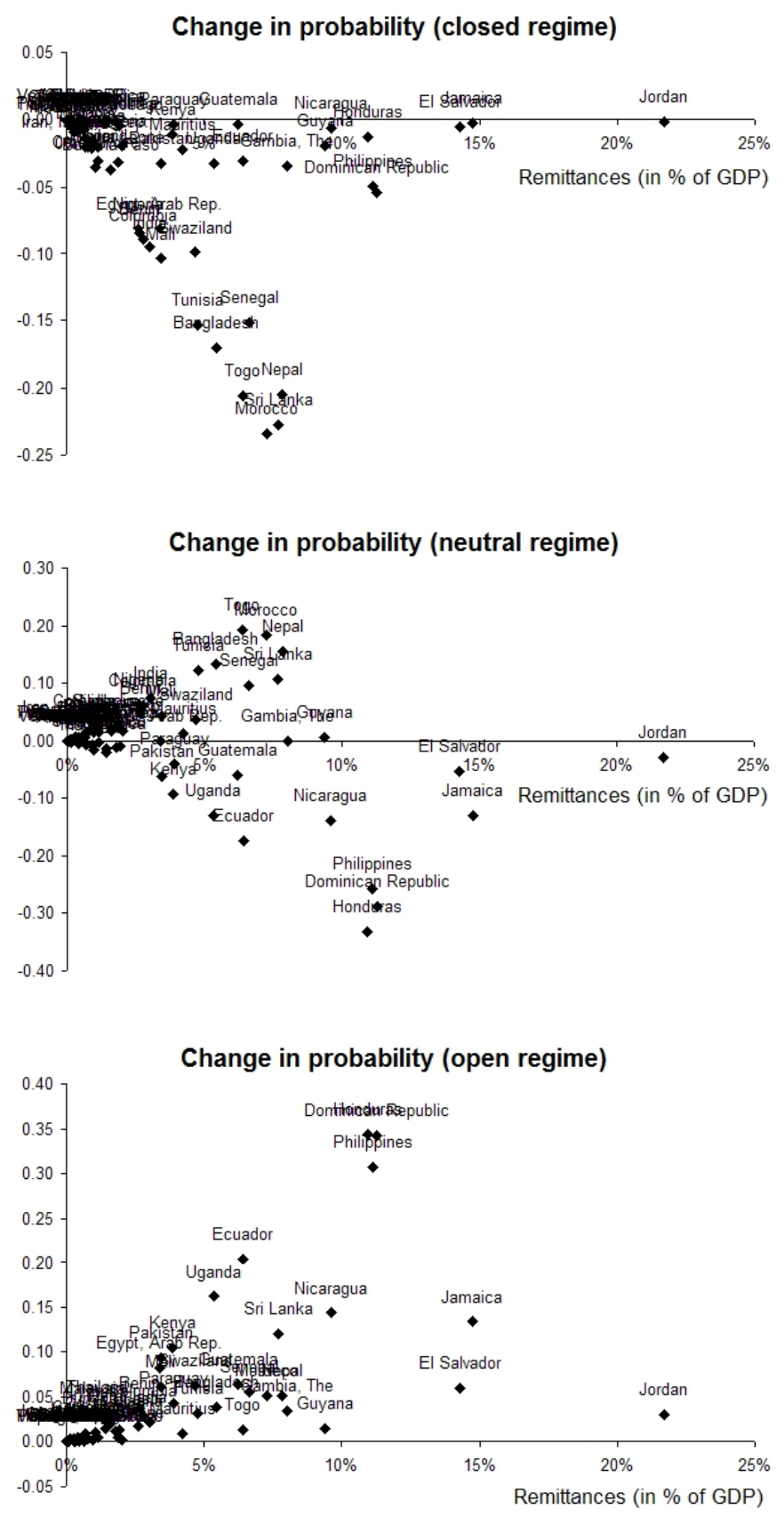
Philippines instead, will strongly increase the probability to end up in a more open category, i.e. neutral for Morocco and open for Philippines, and strongly decrease the probability to remain in the current regime.

\section{Conclusion}

Workers' remittances have greatly increased during recent years, becoming a significant source of income for many developing countries. In addition to their increasing size, the stability and counter-cyclicality of these flows make them an important and reliable source of funds for developing countries. The importance of remittances on human capital investments, poverty reduction, and macroeconomic stability has been widely recognized by researchers and policymakers. Therefore, it is attractive for remittance receiving countries to liberalize their capital account and increase their financial openness in order to attract more remittances through formal channels. Hence, remittances can have an important direct effect on a developing countries' financial openness.

In this paper we investigate the link between remittance receipts and financial openness for a sample of 66 mostly developing countries from 1980-2005. Empirically we use a dynamic generalized ordered logit model to establish the link between remittances and financial openness. In addition, we apply a two-step method akin to two stage least squares to deal with the potential endogeneity of remittances.

We find a highly positive effect of remittances on financial openness, i.e. the more remittances a country receives, the more likely it will be financially open. This positive effect is statistically significant and economically large. Through counterfactual experiments, we show that the probability to be financially opened is higher ceteris paribus for countries which receive a considerable amount of remittances. 


\section{References}

Acosta, P. A., Lartey, E. K. and Mandelman, F. S. (2009). Remittances and the dutch disease, Journal of International Economics 79(1): 102-116.

Acosta, P., Fajnzylber, P. and Lopez, J. (2006). What is the Impact of International Remittances on Poverty and Inequality in Latin America?", in Ozden, C. and Schiff, M. (eds), International Migration, Economic Development and Policy, Chapter 2, Palgrave-Macmillan.

Adams, R. (2006). Remittances Poverty and Investment in Guatemala, in: Ozden, C. and Schiff, M. (eds), International migration, remittances and the brain drain, Chapter 2, Palgrave-Macmillan.

Adams, R. and Page, J. (2005). Do international migration and remittances reduce poverty in developing countries?, World Development 33(10): 16451669 .

Aggarwal, R., Demirguc-Kunt, A. and Martinez Peria, M. (2006). Do workers' remittances promote financial development?, World Bank Policy Research Working Paper 3957.

Agunias, D. R. (2006). Remittances and development: Trends, impacts, and policy options; a review of the literature, Report Migration Policy Institute .

Alesina, A., Grilli, V. and Milesi-Ferretti, G. (1994). The Political Economy of Capital Controls, in Leonardo Leiderman and Assaf Razin, eds., Capital mobility: The impact on consumption, investment, and growth., Cambridge: Cambridge University Press.

Beck, T., Demirguc-Kunt, A. and Levine, R. (2000). A new database on the structure and development of the financial sector, World Bank Economic Review 14(3): 597-605.

Beck, T. and Peria, M. S. M. (2009). What explains the cost of remittances? an examination across 119 country corridors, Policy Research Working Paper Series 5072, The World Bank.

Beine, M., Cosma, A. and Vermeulen, R. (2010). The dark side of global integration: Increasing tail dependence, Journal of Banking \&J Finance 34: 184-192.

Bekaert, G., Harvey, C. and Lundblad, C. (2005). Does financial liberalization spur growth, Journal of Financial Economics 77: 3-55. 
Braun, M. and Raddatz, C. (2007). Trade liberalization, capital account liberalization and the real effects of financial development, Journal of International Money and Finance 26: 730-761.

Brune, N. and Guisinger, A. (2003). The diffusion of capital account liberalization in developing countries, Prepared for delivery at the 2003 Annual Meeting of the American Political Science Association .

Carling, J. (2008). The determinants of migrant remittances, Oxford Review of Economic Policy 24: 581-598.

Chinn, M. and Itô, H. (2002). Capital account liberalization, institutions and financial development: Cross country evidence, NBER Working Paper: Working Paper 8967.

Chinn, M. and Itô, H. (2006). What matters for financial development? capital controls, institutions and interactions, Journal of Development Economics 81: $163-192$.

Chinn, M. and Itô, H. (2008). A new measure of financial openness, Journal of Comparative Policy Analysis 10: 309-322.

Contoyannis, P., Jones, A. and Rice, N. (2004). The dynamics of health in the british household panel survey, Journal of Applied Econometrics 19: 473-503.

Cox-Edwards, A. and Ureta, M. (2003). International migration, remittances, and schooling: Evidence from el salvador, Journal of Development Economics

Defoort, C. (2008). Tendances de long terme en migrations internationales. analyse à partir des 6 principaux pays receveurs, Population-F 63: 317-352.

Dustmann, C. and Kirchkamp, O. (2002). The optimal migration duration and activity choice after remigration, Journal of Development Economics 67: 351372 .

Edison, H., Klein, M., Ricci, L.-A. and Slok, T. (2004). Capital account liberalization and economic performance: Survey and synthesis, IMF Staff Papers 51(2): $220-256$.

Edison, H., Levine, R., Ricci, L.-A. and Slok, T. (2002). International financial integration and economic growth, Journal of International Money and Finance 21(November): 749-776.

Freund, C. and Spatafora, N. (2008). Remittances, transaction costs, and informality, Journal of Development Economics 86: 356-366. 
Giuliano, P. and Ruiz-Arranz, M. (2008). Remittances, financial development, and growth, Journal of Development Economics Article in Press.

Gustafsson, B. and Makonnen, N. (1993). Poverty and remittances in lesotho, Journal of African Economies 2(1): 49-73.

Kaminsky, G. and Reinhart, C. (2000). On crises, contagion, and confusion, Journal of International Economics 51(1): 145-168.

Klein, M. and Olivei, G. (2008). Capital account liberalization, financial depth, and economic growth, Journal of International Money and Finance $\mathbf{2 7}$ (October): $861-875$.

Kose, A., Prasad, E., Rogoff, K. and Wei, S.-J. (2009). Financial globalization: A reappraisal, IMF Staff Papers 56(1): 8-62.

La Porta, R., Lopes-de Silanes, F., Schleifer, A. and Vishny, R. (1999). The quality of government, The Journal of Law, Economics $\&$ Organization 15(1): $222-279$.

Maimbo, S. and Ratha, D. (2005). Remittances, development impact and future prospects, The International Bank for Reconstruction and Development / The World Bank, Washington, DC.

McKinnon, R. (1991). The Order of Economic Liberalization: Financial Control in the Transition to a Market Economy, Johns Hopkins University Press, Baltimore.

Miniane, J. (2004). A new set of measures on capital account restrictions, IMF Staff Papers 51(2): 276-308.

Mundaca, G. (2009). Remittances, financial markets development and economic growth: The case of latin america and caribbean, Review of Development Economics 13(2): 288-303.

Orozco, M. and Lapointe, M. (2004). Mexican hometown associations and development opportunities, Journal of International Affairs 57(2): 1-21.

Quinn, D. (1997). The correlates of change in international financial regulation, American Political Science Review 91(3): 531-551.

Quinn, D. and Toyoda, A. (2008). Does capital account liberalization lead to growth?, The Review of Financial Studies 21(3): 1403-1449.

Rapoport, H. and Docquier, F. (2006). The Economics of migrants' remittances, in S. Kolm and Jean Mercier Ythier, eds., Handbook on the economics of giving, altruism and reciprocity, Vol. 1, Elsevier. 
Reinhart, C. M. and Rogoff, K. S. (2004). The modern history of exchange rate arrangements: A reinterpretation, Quarterly Journal of Economics 119(1): 148.

Schiff, M. and Ozden, C. (2006). International migration, remittances and the brain drain, Palgrave-Macmillan.

Schiff, M. and Ozden, C. (2007). International Migration, Economic Development and Policy, Palgrave-Macmillan.

Singer, D. A. (2009). Migrant remittances and exchange rate regimes in the developing world, Mimeo Massachusetts Institute of Technology .

Spilimbergo, A. (2009). Democracy and foreign education, American Economic Review 99(1): 528-543.

Terza, J., Basu, A. and Rathouz, P. (2008). A two-stage residual inclusion estimation: Addressing endogeneity in health econometric modeling, Journal of Health Economics 27: 531-543.

Tornell, A., Westermann, F. and Martinez, L. (2004). The positive link between financial liberalization, growth and crises, National Bureau of Economic Research Working Paper Series 10293.

Wacziarg, R. and Welch, K.-H. (2008). Trade liberalization and growth: New evidence, The World Bank Economic Review 22(2): 187-231.

Williams, R. (2006). Generalized ordered logit/ partial proportional odds models for ordinal dependent variables, The Stata Journal 6(1): 58-82.

Woodruff, C. and Zenteno, R. (2001). Remittances and microenterprises in mexico, Working Paper, University of California, San Diego, Graduate School of International Relations and Pacific Studies .

Wooldridge, J. (2005). Simple solutions to the initial conditions problem in dynamic, nonlinear panel data models with unobserved heterogeneity, Journal of Applied Econometrics 20: 39-54.

World Bank, . (2006). Global Economic Prospects: Economic Implications of Remittances and Migration, Washington: The World Bank. 


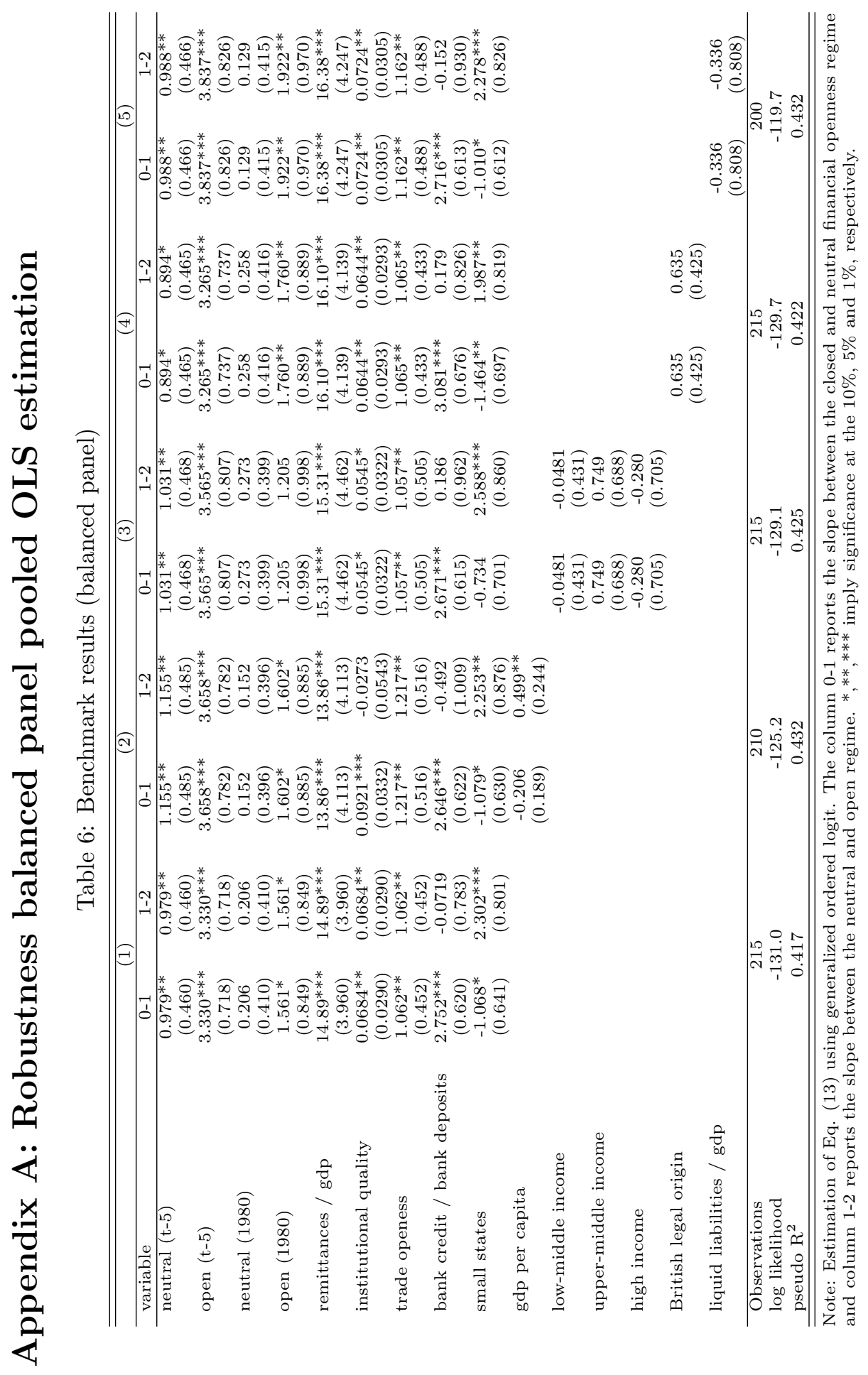




\section{Appendix B: Robustness using System GMM and 2SLS}

Table 7: Robustness using System GMM and 2SLS

\begin{tabular}{|c|c|c|c|c|}
\hline \multirow[b]{2}{*}{ variable } & \multicolumn{2}{|c|}{ unbalanced } & \multicolumn{2}{|c|}{ balanced } \\
\hline & SGMM & $2 \mathrm{SLS}$ & SGMM & $2 \mathrm{SLS}$ \\
\hline kaopen (t-5) & $\begin{array}{c}0.503^{* * *} \\
(0.131)\end{array}$ & $\begin{array}{l}0.208^{* *} \\
(0.0942)\end{array}$ & $\begin{array}{c}0.567^{* * *} \\
(0.154)\end{array}$ & $\begin{array}{c}0.244^{* *} \\
(0.110)\end{array}$ \\
\hline remittances / gdp & $\begin{array}{c}14.92^{* *} \\
(5.813)\end{array}$ & $\begin{array}{c}24.27^{* * *} \\
(7.055)\end{array}$ & $\begin{array}{c}8.486^{* *} \\
(4.056)\end{array}$ & $\begin{array}{c}26.13^{* * *} \\
(7.309)\end{array}$ \\
\hline institutional quality & $\begin{array}{c}0.0272^{* *} \\
(0.0136)\end{array}$ & $\begin{array}{c}-0.0230 \\
(0.0218)\end{array}$ & $\begin{array}{c}0.0233 \\
(0.0147)\end{array}$ & $\begin{array}{c}-0.0338 \\
(0.0227)\end{array}$ \\
\hline trade openess & $\begin{array}{l}0.366^{*} \\
(0.201)\end{array}$ & $\begin{array}{c}0.852^{* * *} \\
(0.256)\end{array}$ & $\begin{array}{l}0.409 * \\
(0.205)\end{array}$ & $\begin{array}{c}0.910 * * * \\
(0.275)\end{array}$ \\
\hline bank credit / bank deposits & $\begin{array}{c}0.416^{* *} \\
(0.208)\end{array}$ & $\begin{array}{c}0.777^{* * *} \\
(0.222)\end{array}$ & $\begin{array}{c}0.445^{* *} \\
(0.219)\end{array}$ & $\begin{array}{c}1.011^{* * *} \\
(0.221)\end{array}$ \\
\hline small states & $\begin{array}{c}0.272 \\
(0.449)\end{array}$ & & $\begin{array}{c}0.293 \\
(0.474)\end{array}$ & \\
\hline Observations & 277 & 276 & 215 & 215 \\
\hline Number of countries & 66 & 65 & 43 & 43 \\
\hline Number of instruments & 32 & & 32 & \\
\hline $\operatorname{AR}(2)$ & 0.280 & & 0.218 & \\
\hline Hansen J (p-value) & 0.172 & 0.163 & 0.194 & 0.295 \\
\hline R-squared & & 0.355 & & 0.401 \\
\hline F-statistic & & 30.25 & & 25.88 \\
\hline Underidentification ( $\mathrm{p}$-value) & & 0.000255 & & 0.000368 \\
\hline
\end{tabular}

Estimation of Equation (13) using System GMM and 2SLS. *,***** imply significance at the $10 \%, 5 \%$ and $1 \%$, respectively. 


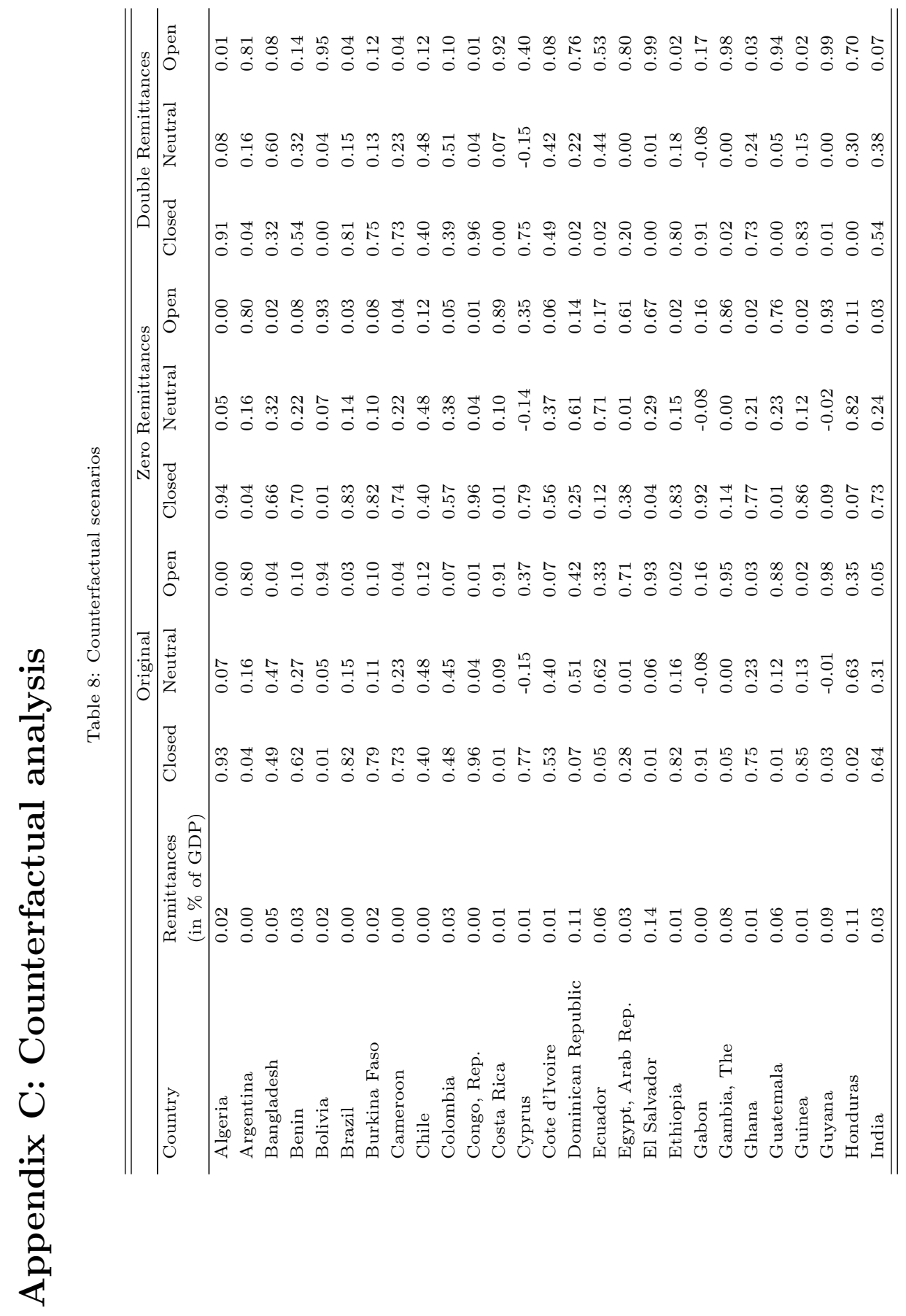




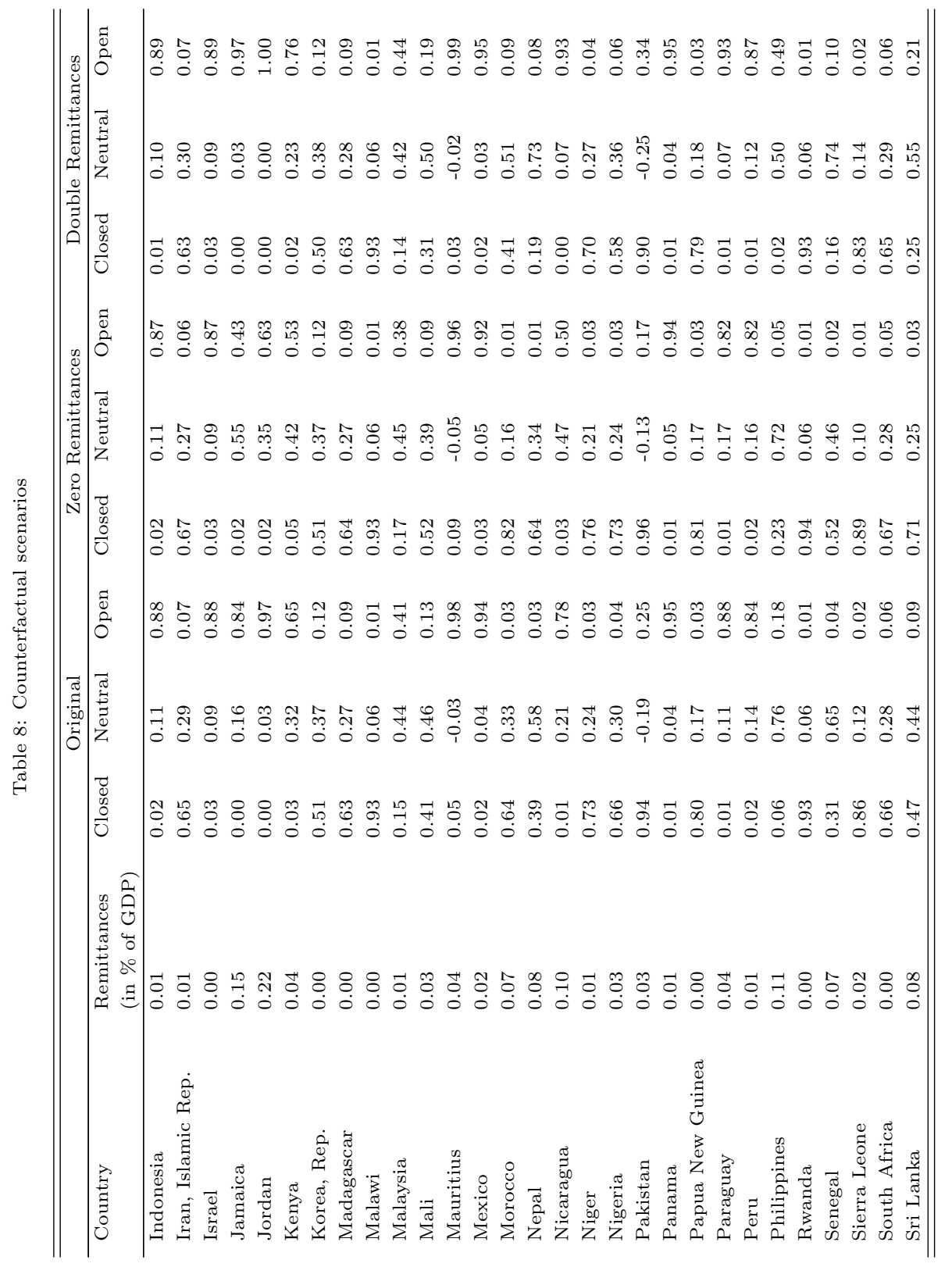




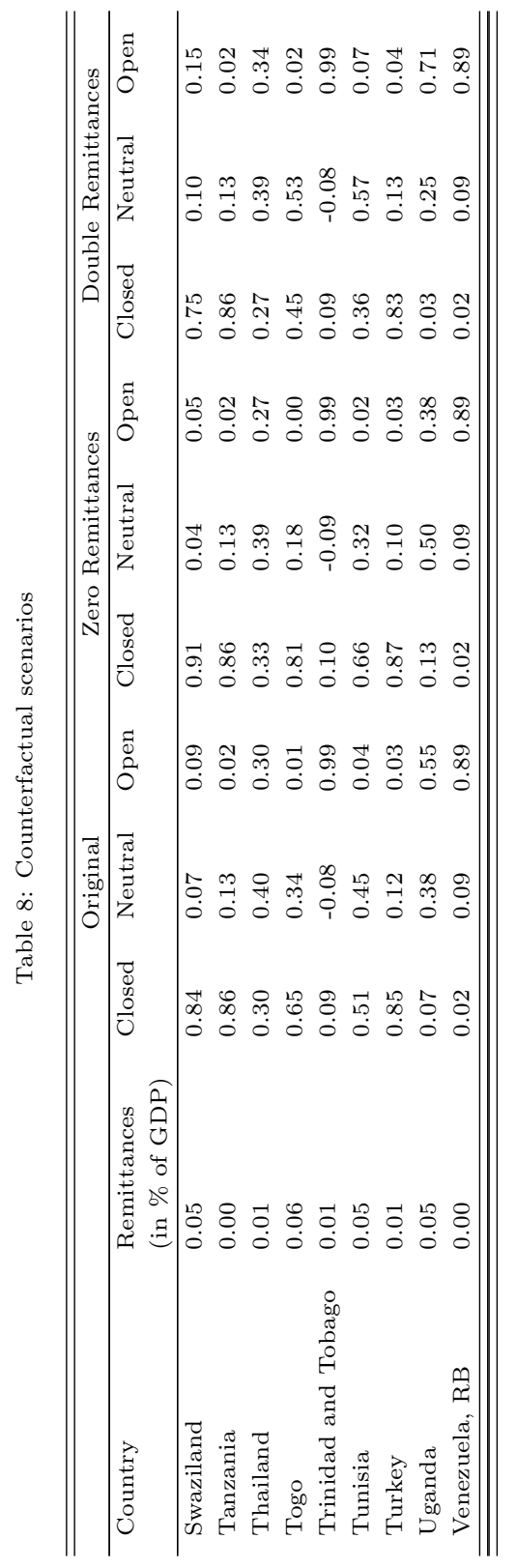




\section{CESifo Working Paper Series}

for full list see www.cesifo-group.org/wp

(address: Poschingerstr. 5, 81679 Munich, Germany, office@cesifo.de)

3029 Erik Snowberg and Justin Wolfers, Explaining the Favorite-Longshot Bias: Is it RiskLove or Misperceptions?, April 2010

3030 Doina Radulescu, The Effects of a Bonus Tax on Manager Compensation and Welfare, April 2010

3031 Helmut Lütkepohl, Forecasting Nonlinear Aggregates and Aggregates with Timevarying Weights, April 2010

3032 Silvia Rocha-Akis and Ronnie Schöb, Welfare Policy in the Presence of Unionised Labour and Internationally Mobile Firms, April 2010

3033 Steven Brakman, Robert Inklaar and Charles van Marrewijk, Structural Change in OECD Comparative Advantage, April 2010

3034 Dirk Schindler and Guttorm Schjelderup, Multinationals, Minority Ownership and TaxEfficient Financing Structures, April 2010

3035 Christian Lessmann and Gunther Markwardt, Decentralization and Foreign Aid Effectiveness: Do Aid Modality and Federal Design Matter in Poverty Alleviation?, April 2010

3036 Eva Deuchert and Conny Wunsch, Evaluating Nationwide Health Interventions when Standard Before-After Doesn't Work: Malawi's ITN Distribution Program, April 2010

3037 Eric A. Hanushek and Ludger Woessmann, The Economics of International Differences in Educational Achievement, April 2010

3038 Frederick van der Ploeg, Aggressive Oil Extraction and Precautionary Saving: Coping with Volatility, April 2010

3039 Ainura Uzagalieva, Evžen Kočenda and Antonio Menezes, Technological Imitation and Innovation in New European Union Markets, April 2010

3040 Nicolas Sauter, Jan Walliser and Joachim Winter, Tax Incentives, Bequest Motives, and the Demand for Life Insurance: Evidence from two Natural Experiments in Germany, April 2010

3041 Matthias Wrede, Multinational Capital Structure and Tax Competition, April 2010

3042 Burkhard Heer and Alfred Maussner, A Note on the Computation of the Equity Premium and the Market Value of Firm Equity, April 2010

3043 Kristiina Huttunen, Jukka Pirttilä and Roope Uusitalo, The Employment Effects of Low-Wage Subsidies, May 2010 
3044 Matthias Kalkuhl and Ottmar Edenhofer, Prices vs. Quantities and the Intertemporal Dynamics of the Climate Rent, May 2010

3045 Bruno S. Frey and Lasse Steiner, Pay as you Go: A New Proposal for Museum Pricing, May 2010

3046 Henning Bohn and Charles Stuart, Population under a Cap on Greenhouse Gas Emissions, May 2010

3047 Balázs Égert and Rafal Kierzenkowski, Exports and Property Prices in France: Are they Connected?, May 2010

3048 Thomas Eichner and Thorsten Upmann, Tax-Competition with Involuntary Unemployment, May 2010

3049 Taiji Furusawa, Kazumi Hori and Ian Wooton, A Race beyond the Bottom: The Nature of Bidding for a Firm, May 2010

3050 Xavier Vives, Competition and Stability in Banking, May 2010

3051 Thomas Aronsson and Erkki Koskela, Redistributive Income Taxation under Outsourcing and Foreign Direct Investment, May 2010

3052 Michael Melvin and Duncan Shand, Active Currency Investing and Performance Benchmarks, May 2010

3053 Sören Blomquist and Laurent Simula, Marginal Deadweight Loss when the Income Tax is Nonlinear, May 2010

3054 Lukas Menkhoff, Carol L. Osler and Maik Schmeling, Limit-Order Submission Strategies under Asymmetric Information, May 2010

3055 M. Hashem Pesaran and Alexander Chudik, Econometric Analysis of High Dimensional VARs Featuring a Dominant Unit, May 2010

3056 Rabah Arezki and Frederick van der Ploeg, Do Natural Resources Depress Income Per Capita?, May 2010

3057 Joseph Plasmans and Ruslan Lukach, The Patterns of Inter-firm and Inter-industry Knowledge Flows in the Netherlands, May 2010

3058 Jenny E. Ligthart and Sebastian E. V. Werner, Has the Euro Affected the Choice of Invoicing Currency?, May 2010

3059 Håkan Selin, Marginal Tax Rates and Tax-Favoured Pension Savings of the SelfEmployed - Evidence from Sweden, May 2010

3060 Richard Cornes, Roger Hartley and Yuji Tamura, A New Approach to Solving Production-Appropriation Games with Many Heterogeneous Players, May 2010 
3061 Ronald MacDonald and Flávio Vieira, A Panel Data Investigation of Real Exchange Rate Misalignment and Growth, May 2010

3062 Thomas Eichner and Rüdiger Pethig, Efficient Management of Insecure Fossil Fuel Imports through Taxing(!) Domestic Green Energy?, May 2010

3063 Vít Bubák, Evžen Kočenda and Filip Žikeš, Volatility Transmission in Emerging European Foreign Exchange Markets, May 2010

3064 Leonid V. Azarnert, Après nous le Déluge: Fertility and the Intensity of Struggle against Immigration, May 2010

3065 William E. Becker, William H. Greene and John J. Siegfried, Do Undergraduate Majors or Ph.D. Students Affect Faculty Size?, May 2010

3066 Johannes Becker, Strategic Trade Policy through the Tax System, May 2010

3067 Omer Biran and Françoise Forges, Core-stable Rings in Auctions with Independent Private Values, May 2010

3068 Torben M. Andersen, Why do Scandinavians Work?, May 2010

3069 Andrey Launov and Klaus Wälde, Estimating Incentive and Welfare Effects of NonStationary Unemployment Benefits, May 2010

3070 Simon Gächter, Benedikt Herrmann and Christian Thöni, Culture and Cooperation, June 2010

3071 Mehmet Bac and Eren Inci, The Old-Boy Network and the Quality of Entrepreneurs, June 2010

3072 Krisztina Molnár and Sergio Santoro, Optimal Monetary Policy when Agents are Learning, June 2010

3073 Marcel Boyer and Donatella Porrini, Optimal Liability Sharing and Court Errors: An Exploratory Analysis, June 2010

3074 Guglielmo Maria Caporale, Roman Matousek and Chris Stewart, EU Banks Rating Assignments: Is there Heterogeneity between New and Old Member Countries? June 2010

3075 Assaf Razin and Efraim Sadka, Fiscal and Migration Competition, June 2010

3076 Shafik Hebous, Martin Ruf and Alfons Weichenrieder, The Effects of Taxation on the Location Decision of Multinational Firms: M\&A vs. Greenfield Investments, June 2010

3077 Alessandro Cigno, How to Deal with Covert Child Labour, and Give Children an Effective Education, in a Poor Developing Country: An Optimal Taxation Problem with Moral Hazard, June 2010 
3078 Bruno S. Frey and Lasse Steiner, World Heritage List: Does it Make Sense?, June 2010

3079 Henning Bohn, The Economic Consequences of Rising U.S. Government Debt: Privileges at Risk, June 2010

3080 Rebeca Jiménez-Rodriguez, Amalia Morales-Zumaquero and Balázs Égert, The VARying Effect of Foreign Shocks in Central and Eastern Europe, June 2010

3081 Stephane Dees, M. Hashem Pesaran, L. Vanessa Smith and Ron P. Smith, Supply, Demand and Monetary Policy Shocks in a Multi-Country New Keynesian Model, June 2010

3082 Sara Amoroso, Peter Kort, Bertrand Melenberg, Joseph Plasmans and Mark Vancauteren, Firm Level Productivity under Imperfect Competition in Output and Labor Markets, June 2010

3083 Thomas Eichner and Rüdiger Pethig, International Carbon Emissions Trading and Strategic Incentives to Subsidize Green Energy, June 2010

3084 Henri Fraisse, Labour Disputes and the Game of Legal Representation, June 2010

3085 Andrzej Baniak and Peter Grajzl, Interjurisdictional Linkages and the Scope for Interventionist Legal Harmonization, June 2010

3086 Oliver Falck and Ludger Woessmann, School Competition and Students' Entrepreneurial Intentions: International Evidence Using Historical Catholic Roots of Private Schooling, June 2010

3087 Bernd Hayo and Stefan Voigt, Determinants of Constitutional Change: Why do Countries Change their Form of Government?, June 2010

3088 Momi Dahan and Michel Strawczynski, Fiscal Rules and Composition Bias in OECD Countries, June 2010

3089 Marcel Fratzscher and Julien Reynaud, IMF Surveillance and Financial Markets - A Political Economy Analysis, June 2010

3090 Michel Beine, Elisabetta Lodigiani and Robert Vermeulen, Remittances and Financial Openness, June 2010 